\title{
Fusarium Wilt Management in Legume Crops
}

\author{
Ana Margarida Sampaio ${ }^{1, * \mathbb{C}}$, Susana de Sousa Araújo ${ }^{1} \mathbb{D}$, Diego Rubiales ${ }^{2}$ \\ and Maria Carlota Vaz Patto ${ }^{1}$ iD \\ 1 Instituto de Tecnologia Química e Biológica António Xavier, Universidade Nova de Lisboa, Avenida da \\ República, Estação Agronómica Nacional, 2780-157 Oeiras, Portugal; saraujo@itqb.unl.pt (S.d.S.A.); \\ cpatto@itqb.unl.pt (M.C.V.P.) \\ 2 Institute for Sustainable Agriculture, Consejo Superior de Investigaciones Científicas, Av. Menéndez Pidal \\ s/n, 14004 Córdoba, Spain; diego.rubiales@ias.csic.es \\ * Correspondence: amsampaio@itqb.unl.pt; Tel.: +351-214469631
}

Received: 29 June 2020; Accepted: 21 July 2020; Published: 25 July 2020

\begin{abstract}
Legumes are among the most important crops worldwide for human and animal consumption. However, yield inconsistency due to susceptibility to pests and diseases strongly affects its production. Among diseases affecting legumes, Fusarium wilt caused by the soil-borne pathogen Fusarium oxysporum Schltdl. ( $F o$ ) is one of the major factors limiting production worldwide. This disease can cause total losses in highly infested fields of some legume species. To minimize yield losses, integrated disease management strategies combining different agronomic practices with the use of resistant varieties should be applied. Although often characterized by a high degree of host specificity, with formae speciales (ff. spp.) and races identified, some Fo ff. spp. can have a broader host range, infecting more than one species, requiring further investigation. In this review, we describe the state of the art on legume Fusarium wilt management achievements, highlighting different aspects such as the use of rhizosphere microbiota as biocontrol agents, crop rotation and the use of resistant varieties. The different methods of identification and characterization of resistance sources, mechanisms as well as the genetic basis of resistance or the development of molecular tools to support legume precision breeding for Fo resistance are discussed.
\end{abstract}

Keywords: Fusarium wilt; legumes; integrated disease management; resistance mechanisms; resistance genetic basis; precision breeding

\section{Introduction}

Fusarium is a genus of filamentous ascomycete fungi that includes important plant pathogens and mycotoxin-producing contaminants of human and animal food [1]. Wilts, blights, root rots and cankers are among the plant diseases caused by this genus [2] and its distribution covers soils and organic substrates all over the world [3]. The genus Fusarium comprises various species complexes, including Fusarium graminearum Schwabe, Fusarium solani (Mart.) Sacc. and Fusarium oxysporum, among others [2]. Fusarium oxysporum (Fo), a ubiquitous soil-borne pathogen that promotes vascular wilt in a wide range of plant species, is one of the most common species [4]. With more than 120 formae speciales (ff. spp.) already identified based on host species specificity [5], it was considered fifth in the top 10 plant pathogens of scientific/economic importance [6]. Fusarium oxysporum is part of the quarantine list of several destinations, as, for example, the European Union, together with Fusarium circinatum Nirenberg \& O’Donnell [7].

Fusarium oxysporum has asexual reproduction, which leads to little potential for gene flow and a low mutation rate, being considered a pathogen with low genotypic diversity [8]. In the absence of a host, Fo can survive extended periods in the soil as chlamydospores [4,9]. In the presence of a host, the infection cycle starts and fungal spores germination and elongation happen towards host plant 
roots in response to specific plant signals $[10,11]$. Root penetration occurs without the formation of specialized structures through the natural openings at the intercellular junctions of cortical cells or through wounds [12]. Once inside the root, hyphae invade the root cortex, penetrate the endodermis, reaching the xylem vessels [13]. Then, the fungus progresses vertically through the xylem, where it moves and multiplies, colonizing the host until a complete plant wilt $[4,14,15]$. Upon plant death, the fungus starts a profuse sporulation on the plant surface, dispersing micro- and macroconidia on the soil for the next cycle of infection [4].

Characteristic disease symptoms include vascular browning, leaf epinasty, stunting, progressive wilting, defoliation and lastly plant death [4,5]. Roots and stems develop a dark-brown discoloration of xylem tissues that can be seen when they are split vertically or cross-sectioned [16]. Wilting appears by a combination of pathogen activity, due to accumulation of fungal mycelium, and host defense responses, as gels and gums production, blocking or plugging the vessels and leading to symptoms resembling water stress [3].

Among the wide range of plant species infected by Fo are tomato (Solanum lycopersicum L.), banana (Musa spp. L.), melon (Cucumis melo L.), cotton (Gossypium spp. L.) and legumes [5]. Grain and forage legumes account for $27 \%$ of the world's primary crop production behind cereals and oilseeds [17]. Their cultivation is over 12 to 15\% of Earth's arable land, highly impacting agronomy, the environment and human and animal nutrition and health [18]. However, the yield of most legumes is still limited and unstable due to environment adaptability challenges and susceptibility to pests and diseases [19]. One of these diseases is Fusarium wilt, which promotes devastating damages in several legume species worldwide [20]. As an example, Fo f. sp. pisi is considered a destructive pathogen of field pea (Pisum sativum L.), and is reported in every country where pea is grown [21]. In the most consumed food grain legume, common bean (Phaseolus vulgaris L.) [22], Fo f. sp. phaseoli is among the most important diseases affecting its production worldwide [23]. In chickpea (Cicer arietinum L.), the second most important global grain legume [22], annual losses due to Fo f. sp. ciceris can reach, under favorable disease conditions, 100\% [24]. In lentil (Lens culinaris Medik.), vascular wilt caused by Fo f. sp. lentis, together with Ascochyta blight, are the two major fungal pathogens responsible for yield losses worldwide [25]. Alfalfa (Medicago sativa L.) and annual medics as barrel medic (M. truncatula L.) are also susceptible to Fusarium wilt, caused by Fo f. sp. medicaginis [26]. Yield losses caused by Fusarium wilt were also identified in several other legume species (Table 1).

As a soil-borne pathogen with the ability to survive in the soil for many decades in the absence of a host, Fo eradication is hard and can only be controlled with integration of several disease management measures. Among all, the use of resistant cultivars is widely known as the most efficient, cost-effective and eco-friendly measure to prevent the huge losses promoted by this pathogen $[19,27]$.

The current work is a review of the efforts made in different aspects related to the breeding of legume crops for resistance against Fusarium wilt.

\section{Fusarium oxysporum Diversity}

Knowledge about pathogenic diversity is essential for designing efficient disease management strategies. Fusarium oxysporum strains that are pathogenic to the same plant species are organized in the same formae speciales (ff. spp.) [28]. Although considered a specialist, Fo ff. spp. can have a broader host range and different Fo ff. spp. can, in some cases, infect the same plant species [29]. Additionally, races and pathotypes have been described, according to their virulence pattern on different plant genotypes within a species [28], for the majority of Fo ff. spp. infecting legumes [30] (Table 1).

Some of these Fo ff. spp., like f. sp. ciceris, are considered monophyletic in origin [31] but still exhibit extensive pathogenic variability. Two pathotypes have been distinguished based on yellowing or wilting syndromes. Eight races $(0,1 \mathrm{~A}, 1 \mathrm{~B} / \mathrm{C}, 2,3,4,5$ and 6$)$ have been described, with races 0 and $1 \mathrm{~B} / \mathrm{C}$ belonging to the yellowing pathotype and the other races, $1 \mathrm{~A}$ through 6 , to the wilting pathotype [16]. 
Pathogenic variability has also been reported in Fo ff. spp. pisi, lentis, phaseoli and tracheiphilum (Table 1).

Some Fo races are only found in certain geographical origins, as Fo f. sp. phaseoli and ciceris races and Fo f. sp. pisi races 5 and 6, while others, as Fo f. sp. pisi race 1 and 2 and Fo f. sp. tracheiphilum race 4 , are distributed worldwide [23,30,32,33].

Table 1. Fusarium oxysporum ff. spp. and respective races causing Fusarium wilt in several legume species.

\begin{tabular}{cccc}
\hline Legume Species & Fo f. sp. & Race & Reference \\
\hline Pea & pisi & $1,2,5,6$ & {$[37,38]$} \\
Chickpea & ciceris & $0,1 \mathrm{~A}, 1 \mathrm{~B} / \mathrm{C}, 2,3,4,5,6$ & {$[39-41]$} \\
Common bean & phaseoli & $1,2,3,4,5,6,7$ & {$[23]$} \\
Lentil & lentis & $1,2,3,4,5,6,7,8$ & {$[42-44]$} \\
Cowpea & tracheiphilum & $1,2,3,4$ & {$[45,46]$} \\
Lupin & lupini & $1,2,3$ & {$[34,35]$} \\
Soybean & glycines & - & {$[47]$} \\
Barrel medicAlfalfa & medicaginis & - & {$[48]$} \\
Pigeon pea & udum & - & {$[49]$} \\
Red clover & - & - & {$[36]$} \\
Faba bean & fabae & & {$[50]$} \\
Birdsfoot trefoil & loti & - & {$[51]$} \\
\hline
\end{tabular}

In lupin, three races of Fo f. sp. Iupini $(1,2,3)$ were described as specific to different lupin species [34,35]. By contrast, in other Fo ff. spp. infecting legumes, races have not been identified so far, and in some cases, as in the causal agent of Fusarium wilt in red clover, an ff. spp. designation has not been assigned yet [36].

The examples above are in accordance with the high host specificity that usually characterizes Fo ff. spp. However, there are examples of Fo ff. spp. revealing a broader host range, infecting more than one legume species. In fact, it is believed that only about half of the currently described Fo ff. spp. are pathogenic to only one host plant [29]. Besides pea, Fo f. sp. pisi can also infect chickpea [52]. Moreover, Fo f. sp. tracheiphilum race 1 from cowpea was found to infect soybean plants [53]. Probably, if more potential hosts, in this case if more legumes, had been tested, more Fo ff. spp. would not be associated with only a single legume host species. Still, there might be numerous species that even when they do not develop symptoms can allow extensive root and stem colonization that might have a direct effect on the inoculum build-up of the pathogen. Asymptomatic plants can serve as carriers of the pathogen. For instance, even when Fo f. sp. ciceris is pathogenic only on Cicer spp., it can invade root tissues of other legumes such as common bean, faba bean, lentil, pea and pigeon pea without causing external symptoms [16]. Similarly, Fo f. sp. phaseoli can colonize roots of hyacinth bean, jack bean, lima bean, cowpea and others, also without causing visible symptoms [54]. Knowing the host range is therefore crucial in designing management strategies, revealing how alternative hosts can serve as fungal reservoirs, spreading the disease and leading to unexpected outbreaks. Additionally, if the same Fo f. sp. can infect two legume species, the knowledge on resistance developed for one of these species can be useful also for resistance improvement in the other.

\section{Fusarium Wilt Integrated Disease Management}

The management of Fusarium wilt disease is a difficult task, not only in legumes but in every plant species and relies on the integration of different disease management approaches. Pathogen elimination and the reduction of the amount and viability of the fungal inoculum are the main targets of the disease control measures [16]. 


\subsection{Chemical Control}

Chemical control is one of the disease management practices for soil-borne diseases. However, this approach has numerous disadvantages at economical, environment and public health levels [55].

Until the implementation of a global agreement to protect the ozone layer (Montreal Protocol, 1986), methyl bromide was widely used as fumigant due to its high efficiency against soil-borne diseases [56]. Alternative fumigants to methyl bromide such as carbendazim, dazomet, chloropicrin and 1,3-dichloropropene are among the presently most frequent used to combat Fusarium wilt. In the past, chloropicrin and dazomet controlled pea wilt satisfactorily in severely infested soils [57]. However, lethal consequences on the Rhizobium Frank soil microbial communities were also revealed, namely by chloropicrin application. Nevertheless, it is important to reinforce that their frequent and indiscriminate use can not only alter soil microbial community composition but also may damage aquatic ecosystems, and even lead to the development of fungicide resistance $[27,58]$. There is great public concern on environmental issues leading to recommendations to explore more environment-friendly control approaches. As an example, the European Union has issued numerous directives regarding the reduction of phytochemicals in farming systems [59]. Several alternatives have already been explored for legumes Fusarium wilt management and are described below.

\subsection{Biological Control}

Rhizosphere colonization with beneficial microorganisms has been shown to have positive results in Fusarium wilt control. The use of Trichoderma fungal species is among the most used in Fusarium wilt biological control. Trichoderma hamatum (Bonord.) Bainier treatment in lentil seedlings reduced Fo f. sp. lentis colonization, while soil application of Trichoderma harzianum Rifai at common bean and chickpea growing areas reduced efficiently Fo f. sp. phaseoli and Fo f. sp. ciceris infection rates, respectively [60-62].

Bacteria also have biocontrol potential for Fusarium wilt management. Bacillus subtilis (Ehrenberg) Cohn demonstrated promising results, reducing in $25 \%$ the final chickpea wilt disease in growth chamber experiments [62]. However, chickpea field soil treatment with Pseudomonas fluorescens Migula showed the best Fo f. sp. ciceris suppression [63]. Although Streptomyces spp. are less studied than other biocontrol agents [64,65], a Streptomyces isolate (AC-19) and another Bacillus isolate (BC-10) showed high potential for Fo biocontrol in chickpea with a combined application at the seed and soil level [66]. It has also been shown that a consortium of four rhizobacteria, including Serratia, Pseudomonas, Rahnella and Bacillus spp., controls Fo on chickpea more efficiently than each bacterium applied separately [67]. Bacillus subtilis has been reported to control Fo ff. spp. fabae and lupini, being more effective when applied together with Trichoderma pseudokoningii Rifai [68]. The potential of Bacillus spp. as a biocontrol agent in pigeon pea seeds was also reported using B. brevis both in pot and field conditions [69].

Arbuscular mycorrhizal fungi (AMF) and bacterial Rhizobium species are symbionts with an important role in plant productivity and nutrition but also in plant disease resistance, namely against soil-borne diseases $[70,71]$. In chickpea, the application of these two symbionts individually was demonstrated to be more effective in disease reduction than when applied simultaneously [72]. Fusarium oxysporum disease management in the field through application of Rhizobium isolates was only reported in chickpea plants and, unfortunately, with no significant effect on the reduction of wilted plants on a susceptible cultivar [73].

Non-pathogenic Fo are also considered compatible biocontrol agents. They can suppress disease development by the pathogenic Fo, competing for space and nutrients and even inducing resistance [74]. In chickpea, the use of a non-pathogenic Fo f. sp. ciceris isolate reduced the disease by $18 \%$ under controlled conditions [62]. Similarly, pea inoculation with a tomato non-pathogenic Fo strain revealed an early stimulation of the defense responses on roots [75]. The effect of such non-pathogenic isolates can be increased when they are applied combined with B. subtilis or P. fluorescens [76]. However, field studies are needed to confirm the applicability of this hypothesis. 
Although promising, biocontrol agents could be influenced by the plant genotype, inoculum density and the environmental conditions $[62,63,76]$, which could make difficult their integration in Fusarium wilt management strategies. Nevertheless, a well-balanced use of biocontrol agents together with cultural control measures can result in a profitable Fo disease management improvement.

\subsection{Cultural Control}

Human activity is the main cause for the development of new Fo infestations [77]. However, also human proper cultural practices can reduce Fo incidence and damage. Pathogen dissemination can happen through contaminated and infected seeds. The use of certified pathogen-free seeds or their effective quarantine are important measures for Fusarium wilt control [78]. As an example, and to prevent $F o$ f. sp. phaseoli long-distance dissemination by contaminated seeds, a rapid real-time polymerase chain reaction (qPCR) protocol was developed to detect $F o$ in common bean seeds [79]. To optimize the use of Fo-free seeds, it is important that they are planted in non-infested soils. When land is not limiting, avoiding infested soils can significantly reduce disease incidence [80]. However, most of the time this is not possible. In these cases, the establishment of cultural practices as soil solarization and crop rotation is important to minimize Fo inoculum incidence.

Solarization by soil coverage with mulching materials to increase soil temperature can reduce Fo inoculum in soil [27]. However, this is costly and must therefore be considered in accordance with disease prediction and economy of the crop harvest. Yet, soil solarization, in the case of a legume crop, can have both beneficial and detrimental effects, such as the decay of Rhizobium soil populations [81].

The adoption of strategies to increase soil organic matter can have positive results on the management of soil-borne diseases as Fo. One of the most efficient strategies to improve soil quality, decrease soil-borne pathogens and simultaneously enhance soil microbial activity is biofumigation [82]. Crops belonging to the Brassicaceae family, as, for example, broccoli, are excellent green manures by producing a sulfur compound, glucosinolate, toxic to several soil pathogens, being effective in their control [27]. In chickpea fields, Brassica juncea (L.) Czern. demonstrated to be the most efficient brassica species tested in Fusarium wilt severity reduction [83].

In soil-borne pathogens, like Fo, crop rotation may reduce the inoculum in the soil [16] but be less effective due to the ability of Fo chlamydospores to survive in the soil for a long time [4] and also to the inoculum multiplication in roots of symptomless carriers [84]. In the case of the chickpea Fusarium wilt pathogen, Fo chlamydospores can survive in the soil for more than six years, with an extended crop rotation with a proper non-host plant species being necessary for significant pathogen decay in the soil [85]. When designing rotations, alternative hosts, even asymptomatic ones, should be avoided. Further, weed management might be important, since Fo can colonize roots of asymptomatic common dicotyledonous weeds in soybean fields, serving as an Fo reservoir [86]. Unfortunately, the optimization of promising legume crop rotations is hampered by the lack of information existing on the host/non-host range of all the other legume-infecting Fo ff. spp., as well as on the plant species inducing Fo ff. spp. chlamydospores rhizosphere germination.

Soil detection of Fo f. sp. ciceris by a qPCR protocol [87] and Fo f. sp. pisi by PCR-RFLP (restriction fragment length polymorphism) [88] is already possible. These approaches would allow to predict the risk of disease in chickpea and pea production areas and to confirm the efficiency of the cultural practices in the reduction of the Fo soil inoculum. Due to their advantages in epidemiological control, the use of approaches like these should be considered for the detection of infested soils with other Fo ff. spp. infecting legumes.

Besides all the previously described control practices, the use of resistant varieties is widely recognized as the safest, most economical and effective crop protection method to control soil-borne diseases $[19,27]$. The development of legume Fo-resistant varieties through plant breeding is a long process with several steps, constantly integrating novel research developments to increase efficiency in releasing solutions to fight new Fo ff. spp. or races infecting legumes. 


\section{Breeding for Fusarium Wilt Resistance in Legumes}

The main goal of breeding for Fusarium wilt resistance is the development of resistant varieties that do not develop disease symptoms or where the disease appears late, building up slowly, and resulting in little damage to the crop. To achieve that, the screening for and characterization of resistance sources with potential for incorporation into breeding schemes is an initial but very important step.

\subsection{Resistance Screening Methods}

For searching for novel sources of resistance against Fusarium wilt, efficient screening methods are essential. The identification of resistance sources starts normally with mass screenings of large germplasm collections of accessions from the same, or less frequently, related legume species. The resistance mechanisms of the most promising resistance sources identified through these mass approaches can then be further explored through more detailed screening methods in a smaller number of selected accessions.

\subsubsection{Mass Screening Methods}

Mass screening can be performed directly in the field or under controlled conditions using different parameters (Table 2). These parameters are based mainly on whole plant, leaves or xylem direct observations, and less commonly, on the root aspect.

Field screening allows the simultaneous screening of large amounts of genetic material under natural environmental conditions [30]. A naturally infested field can be used [89] but the most common alternative approach is the use of artificially infected fields through wilt-sick plots. Homogenization of the disease pressure across the field is crucial [90]. Furthermore, the presence of naturally occurring additional soil pathogens may interfere with the results [30]. Indeed, it was already reported that co-infection of chickpea by Fo and nematodes decreases valuable resistance against the fungus, increasing disease severity in resistant accessions and even more the disease severity in susceptible cultivars [91-94].

Controlled environments, including greenhouse or growth chambers, can be managed to establish optimum environmental conditions for disease development, allowing the screening all year round, also out of crop season [30]. Although considered an efficient approach in several legume species, controlled environment inoculation processes cannot completely simulate the disease progression in the field. The inoculation techniques that normally precede screening for Fo resistance under controlled conditions have been reviewed previously by Haglund [95]. The most used one is the root dip method, where around one-third of the root system from 7- to 10-day-old seedlings is removed and the remaining root system is immersed in the inoculum suspension. This method wounds the root system and allows direct contact with the pathogenic spores, leading to massive entry of the pathogen directly in the xylem through these wounds, allowing faster and stronger symptom development than other methods like water spore suspensions. However, this inoculation process is a priori excluding the screening for resistance mechanisms that might be associated with the root penetration stage [96]. Yet, there are clear indications of the existence of other resistance mechanisms acting at earlier stages. Focus on identifying variation for these mechanisms would add layers of resistance that will increase the efficacy and durability of major resistance genes.

Irrespective of the approach used, plant response to infection by Fo is highly influenced by temperature. The most extreme example is the shift in response in race-specific resistance of $\mathrm{cv}$. Ayala to race $1 \mathrm{~A}$ of $F o \mathrm{f}$. sp. ciceris, in which a $3{ }^{\circ} \mathrm{C}$ increase in the incubation caused a shift from resistance (at $24^{\circ} \mathrm{C}$ ) to susceptibility (at $27^{\circ} \mathrm{C}$ ) under controlled conditions [97]. In the field, also different disease responses were detected on this cultivar depending on the sowing date, changing from resistant to moderately susceptible if sowing occurs under warmer temperatures [97]. 
Table 2. Mass screening methods used for Fusarium wilt symptoms evaluation in different legume species.

\begin{tabular}{|c|c|c|}
\hline Environment & Disease Assessment & Species and Reference \\
\hline \multirow{3}{*}{ Field } & Disease incidence (percentage of dead plants) & $\begin{array}{l}\text { Chickpea }[98-101] ; \\
\text { Lentil }[89,90,102]\end{array}$ \\
\hline & $\begin{array}{l}\text { Scale based on percentage of leaves } \\
\text { showing symptoms }\end{array}$ & $\begin{array}{l}\text { Chickpea }[24,97,103] \\
\text { Lentil }[104]\end{array}$ \\
\hline & Scale based on $\%$ of xylem discoloration & Alfalfa [105] \\
\hline \multirow{7}{*}{ Controlled conditions } & Disease incidence (percentage of dead plants) & $\begin{array}{l}\text { Pea }[106,107] \\
\text { Lentil }[44,108]\end{array}$ \\
\hline & Percentage infected leaves & $\begin{array}{c}\text { Pea [109]; } \\
\text { Barrel medic [110] }\end{array}$ \\
\hline & $\begin{array}{l}\text { Scale based on percentage of leaves } \\
\text { showing symptoms }\end{array}$ & $\begin{array}{c}\text { Chickpea [91,97]; } \\
\text { Lentil [102,111]; } \\
\text { Common bean [112,113]; } \\
\text { Barrel medic [114] }\end{array}$ \\
\hline & Visual scale at leaf level & $\begin{array}{c}\text { Pea [109,115-117]; } \\
\text { Chickpea [118]; } \\
\text { Lentil [43,89]; } \\
\text { Common bean [119]; } \\
\text { Barrel medic [26]; } \\
\text { Birdsfoot trefoil [120] }\end{array}$ \\
\hline & Scale for root symptoms & Pea [121] \\
\hline & Scale based on percentage xylem discoloration & $\begin{array}{c}\text { Common bean [113]; } \\
\text { Cowpea [32]; } \\
\text { Alfalfa [105]; } \\
\text { Lupin [122]; } \\
\text { Red clover [36] }\end{array}$ \\
\hline & Infra-red imaging (plant temperature) & Pea [123] \\
\hline
\end{tabular}

Promising resistance sources identified by mass studies can be further characterized using more detailed approaches. The details revealed by these approaches can provide valuable insights on the physical and chemical resistance mechanisms behind the identified resistances.

\subsubsection{Detailed Screening Methods}

The first report on the cellular basis of host-Fo interaction was performed using transmission electron microscopy [124]. After that, histology of Fo infection has been studied in detail by light, electron, fluorescence and laser confocal microscopy. Some of the most relevant studies are summarized in Table 3.

Light microscopy, commonly used together with plant staining, allowed an initial characterization of the resistance mechanisms among pea $[75,109,125,126]$, lentil [127] and chickpea $[128,129]$. Some of these results have been further confirmed by electron microscopy $[75,128,129]$, a detailed 3-dimensional approach very useful in the morpho-functional characterization of cellular structures [130]. The use of transformed plant pathogens with fluorescent reporter proteins provides important information for plant pathogen interaction studies, making fluorescence and laser confocal microscopy progressively more used in this type of study. 
Table 3. Detailed screening methods used for Fusarium wilt disease symptoms analysis in different legume species.

\begin{tabular}{cc}
\hline Screening Method & Species and Reference \\
\hline Light microscopy & Pea $[75,109,125,126] ;$ \\
Lentil $[127] ;$ \\
Chickpea $[128,129]$ \\
\hline Scanning electron microscopy (SEM) & Common bean [131,132]; \\
\hline Transmission electron microscopy (TEM) & Chickpea [128,129] \\
\hline Fluorescence microscopy & Pea [75,124]; \\
\hline & Common bean [132] \\
\hline Laser confocal microscopy & Barrel medic [26] \\
& Chickpea [129,133-135]; \\
& Common bean [136]; \\
& Barrel medic [26]
\end{tabular}

The detailed screening methods here described provide a better understanding of the host resistance mechanisms (Section 4.2), enabling the appropriate deployment of Fusarium wilt resistance in legumes.

\subsection{Resistance Mechanisms Against Fo}

Legume resistance against Fo has been reported to operate at different stages of the infection process, preventing or retarding fungal penetration and colonization of the root epidermis, cortex and endodermis as a mechanism of extravascular defense, or later in the root xylem and even later in the stem, as mechanisms of vascular resistance $[125,133]$. The main resistance mechanisms are present among root tissues, which is the entrance site for Fo. Similar host root resistance responses have been found among different legume species and they are summarized in Figure 1.

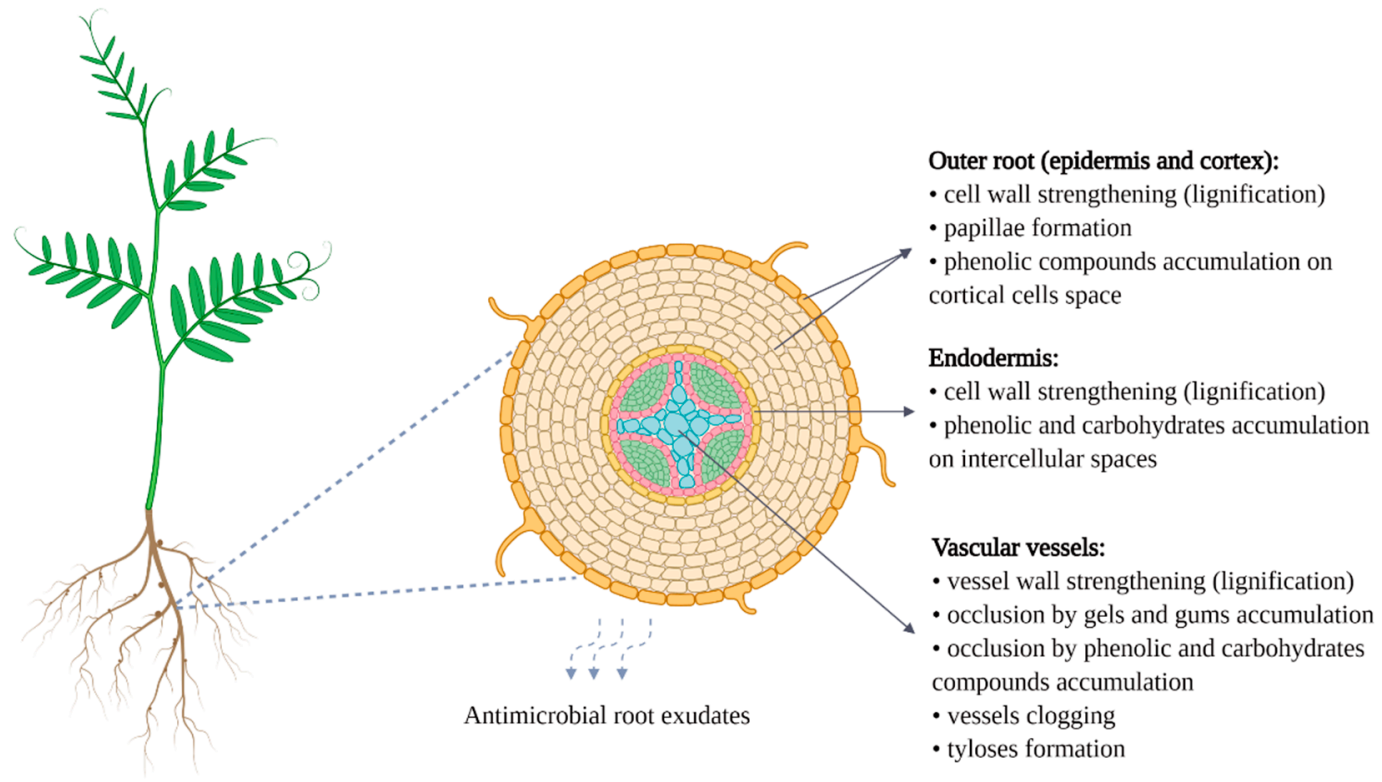

Figure 1. Legumes' common root resistance mechanisms against Fusarium wilt (schematic representation made in (CBioRender-biorender.com).

Root exudates are known to stimulate the germination of Fo [137]. Therefore, exudates from different species or even different accessions within a given species might differ in the content of inhibitory or stimulatory metabolites. A constitutive pre-penetration defense mechanism inhibiting 
Fo germination was detected in roots exudates from resistant accessions of chickpea and pea. Among those, the release of antimicrobial compounds as phytoalexins was the most common [138-140]. Other molecules with reported inhibitory effects on conidia germination and hyphal growth of $F o$ are chitinases, glucanases, proteases and lipid transfer proteins [141]. For instance, chickpea cultivars with different levels of susceptibility to Fo varied in their production of chitinase, protease and glucanase in roots, leading to distinct effects on Fo spore germination and hyphal growth [142]. After penetration, almost all resistant legume accessions from different species were characterized to efficiently stop the pathogen before reaching the xylem $[40,125,133,135,138]$. Cell wall strengthening due to lignin deposition was a common resistance phenomenon [125,139]. In fact, an increased concentration of lignin biosynthetic enzymes such as caffeoyl-CoAO-methyltransferase on resistant pea Fo-inoculated roots and their upregulation on resistant chickpea Fo-inoculated roots have been already detected by proteomic and transcriptomic analysis [143,144]. Accumulation of phenolic compounds at inter- or intracellular spaces was also frequent along legume root tissues to block fungus progression [125]. Nevertheless, some resistance mechanisms were found to be tissue-specific from the outer root area or from the vascular tissue. Papilla-like structures at sites of hyphae penetration were only detected at the first layers of defense [125], while at the vascular tissue, a battery of different resistance mechanisms undetectable at the root epidermis, cortex and endodermis tissues appeared. Vascular tissue occlusion by dense gels, gum-like substances or by phenolic and carbohydrates accumulation was detected in the xylem vessels in response to Fo infection, eventually leading to vessels clogging [40,125-127,131,145]. In lentil, also tyloses, outgrowths of parenchyma plant cells that are projected into the xylem vessels, were detected in the vascular tissue after Fo infection in resistant accessions [127]. However, this defense mechanism was not detected in the other revised legume species.

After a better understanding of the resistance mechanisms deployed by resistance legume sources at the physical and chemical levels, unveiling the genetic basis of these resistance mechanisms is fundamental. Only by knowing what is controlling the resistance is it possible to develop accurate breeding tools against Fusarium wilt.

\subsection{Genetic Basis of Resistance Against Fo}

Precision breeding for Fusarium wilt resistance is only possible by knowing the genetic basic of resistance. Through linkage mapping and genome-wide association studies (GWAS), different types of resistance against $F o$, qualitative and quantitative, depending respectively on a single or several genes, were characterized among legumes.

\subsubsection{Monogenic Resistance}

Monogenic resistance against $F o$ is the most used in breeding. The known resistance genes and their genetic location are shown in Table 4 .

In chickpea, the complete resistance against four races of Fo f. sp. ciceris (races 2, 3, 4 and 5) is governed by single genes [146-149]. Interestingly, all these genes were located in the same linkage group (LG), LG2. In pea, this does not happen, and the monogenic resistance to Fo f. sp. pisi race 1 and 5 was mapped on a different LG [150-153]. In common bean, monogenic resistance against Fo f. sp. phaseoli race 1 and 2 was identified in the Andean gene pool [154], however, the LG location of these genes is still unknown.

In lentil, although races of Fo f. sp. lentis have been recently revealed, the resistance basis was still not defined for each race individually, being generally described as controlled by a single gene $[155,156]$.

\subsubsection{Oligogenic/Polygenic Resistance}

A major resistance quantitative trait locus (QTL) located in LG4, Fnw4.1 (Fusarium near wilt), accompanied by two additional QTLs located in LG3, was identified in pea against Fo f. sp. pisi race 2 [107]. 
In chickpea, digenic response to Fo f. sp. ciceris race 0 and 4 was revealed, while resistance against Fo f. sp. ciceris race 1A was described as controlled by three genes [157-163]. In alfalfa, also two genes were described as involved in resistance against resistance to Fo f. sp. medicaginis [164], however, the genetic basis of the resistance among barrel medics, species from the same genera, infected by Fo f. sp. medicaginis remains unknown. Regarding lentil, five genes controlling resistance to Fo f. sp. lentis were detected [165].

In common bean, nothing was known about the genetic basis of resistance against Fo f. sp. phaseoli race 6 before a recent GWAS study using a Portuguese accessions collection [125]. In this study, an oligogenic control, with nine SNPs (single-nucleotide polymorphisms) associated with seven candidate resistance genes on chromosomes 4, 5, 7 and 8, was detected [119]. Although not all the phenotypic variance could be explained by these SNPs, all resistant accessions had an Andean origin, as in the resistance described against Fo f. sp. phaseoli race 1 and 2, or an admixed nature between Andean and Mesoamerican gene pools [119]. Conversely, in the case of Fo f. sp. phaseoli race 4, polygenic resistance was found among Mesoamerican common bean populations [166,167]. Additionally, using a common bean recombinant inbred line (RIL) population obtained from a cross between Durango and Mesoamerican germplasms (the Fo f. sp. phaseoli resistant parent), three quantitative trait loci (QTLs) were associated with Fo f. sp. phaseoli race 4 resistance. One QTL in LG10 was identified as the major QTL responsible for the observed phenotypic variance, followed by two additional QTLs in LG3 and LG11 [113].

Legume known resistance QTLs involved in oligogenic/polygenic control and their locations are summarized in Table 4.

Table 4. Resistance genes and quantitative trait loci (QTLs) against Fo ff. spp. and races infecting legumes, their genetic location (linkage group/chromosome) and linked markers.

\begin{tabular}{|c|c|c|c|c|}
\hline Species & Fo f. sp. & $\begin{array}{c}\text { Linkage } \\
\text { Group/Chromosome }\end{array}$ & $\begin{array}{l}\text { Resistance } \\
\text { Genes/QTLs }\end{array}$ & $\begin{array}{l}\text { Markers Linked to the } \\
\text { Resistance Genes/QTLs }\end{array}$ \\
\hline \multirow{3}{*}{ Pea } & pisi race 1 & $\begin{array}{c}\text { LG3 }\left(\operatorname{chr} 5^{(1)}\right) \\
{[150,151]}\end{array}$ & $F w[150,151]$ & $\begin{array}{c}\text { ACG:CAT_222 (1.4) [151]; } \\
\text { Fw_Trap_480 (1.2), } \\
\text { Fw_Trap_340 (1.2) and } \\
\text { Fw_Trap_220 (1.2) [168] }\end{array}$ \\
\hline & pisi race 2 & 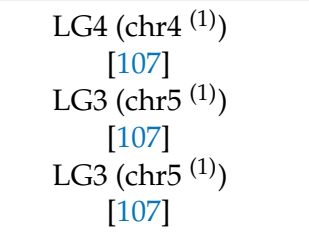 & $\begin{array}{c}\text { Fnw4.1; } \\
\text { Fnw3.1; } \\
\text { Fnw3.2 [107] }\end{array}$ & $\begin{array}{c}\text { AC22_185 and } \\
\text { AD171_197 [107]; } \\
\text { AB70_203 and } \\
\text { AD180_60 [107] } \\
-\end{array}$ \\
\hline & pisi race 5 & $\begin{array}{l}\text { LG2 }\left(\operatorname{chr6} 6^{(1)}\right) \\
{[152,153]}\end{array}$ & Fwf $[152,153]$ & U693a (5.6) [153] \\
\hline
\end{tabular}


Table 4. Cont.

\begin{tabular}{|c|c|c|c|c|}
\hline Species & Fo f. sp. & $\begin{array}{c}\text { Linkage } \\
\text { Group/Chromosome }\end{array}$ & $\begin{array}{c}\text { Resistance } \\
\text { Genes/QTLs }\end{array}$ & $\begin{array}{c}\text { Markers Linked to the } \\
\text { Resistance Genes/QTLs }{ }^{(3)}\end{array}$ \\
\hline \multirow{9}{*}{ Chickpea } & \multirow[t]{2}{*}{ ciceris race 0} & LG5 [169] & $\begin{array}{c}f o c-0_{1} / F o c-0_{1}{ }^{(2)} \\
{[157]}\end{array}$ & $\begin{array}{c}\text { OPJ20 }_{600}(3.0) \text { and TR59 (2.0) } \\
\text { [157,169]; H2I20, } \\
\text { CaGM20820, CaGM20889 } \\
\text { and TS43 [170]; }\end{array}$ \\
\hline & & LG2 [158] & foc- $\mathrm{O}_{2} / \mathrm{Foc}_{2}{ }^{(2)}[158]$ & TA59 and TS47 [158] \\
\hline & \multirow[t]{2}{*}{ ciceris race $1 \mathrm{~A}$} & LG2 [158] & $\begin{array}{l}\text { foc-1 (syn. H1) } \\
\text { [159-162]; }\end{array}$ & $\begin{array}{c}\text { H3A12 (3.9) and TA110 (2.1) } \\
\text { [171]; TA59 (4.4), TA96 (4.9), } \\
\text { TA27 (4.9) and CS27A (4.9) } \\
\text { [172]; TR19, TA194 and } \\
\text { TA660 [173] }\end{array}$ \\
\hline & & - & h2, H3 [159-162] & - \\
\hline & ciceris race 2 & LG2 [158] & foc-2 [146] & $\begin{array}{c}\text { TA96 (1.5), TA27 (1.5), TR19 } \\
\text { (4.9) and CS27A (1.5) [172]; } \\
\text { H3A12 (2.7) [171]; TA110 } \\
\text { and TA37 [174] }\end{array}$ \\
\hline & ciceris race 3 & LG2 [158] & $\begin{array}{c}\text { foc-3/Foc-3 }{ }^{(2)} \\
{[146,147]}\end{array}$ & $\begin{array}{c}\text { TA59 }(0.5), \text { TA96 }(0.5), \text { TA27 } \\
(0.5) \text { and CS27A }(0.5) \\
{[147,172] ; \text { H1B06y }(0.2) \text { and }} \\
\text { TA194 (0.7) [171] }\end{array}$ \\
\hline & \multirow[t]{2}{*}{ ciceris race 4} & LG2 [158] & foc-4 [146]; & $\begin{array}{c}\text { TA59 (3.8), TA96 (3.3), TA27 } \\
\text { (3.3) and TR19 (3.1) [172]; } \\
\text { CS27 (3.7) [175]; } \\
\text { R-2609-1 (2.0) and } \\
\text { OP-U17-1 (4.1) [176] }\end{array}$ \\
\hline & & - & $\begin{array}{l}\text { Two recessive } \\
\text { genes [163] }\end{array}$ & - \\
\hline & ciceris race 5 & LG2 [158] & $\begin{array}{c}\text { foc }-5 / F o c-5^{(2)} \\
{[146,149]}\end{array}$ & $\begin{array}{c}\text { TA59 (2.4), TA96 (2.9), and } \\
\text { CS27A (2.9) [172]; TA27 (2.9) } \\
\text { [172,175]; SPA and } \\
\text { PRP-RGA1 [177] }\end{array}$ \\
\hline \multirow[t]{2}{*}{ Lentil } & \multirow{2}{*}{ lentis } & LG6 [156] & Fw [155]; & $\begin{array}{l}\text { OP-KI5900 (10.8) [155]; } \\
\text { SSR59-2B (8) and } \\
\text { p17m30710 (3.5) [156] }\end{array}$ \\
\hline & & - & $\begin{array}{l}\text { Fuw }_{1}, \text { Fuw }_{2}, \text { Fuw }_{3}, \\
\text { Fuw }_{4}, \text { Fuw }_{5}[165]\end{array}$ & - \\
\hline \multirow{3}{*}{$\begin{array}{l}\text { Common } \\
\text { bean }\end{array}$} & phaseoli race 1 & - & Fop1 [154] & - \\
\hline & phaseoli race 2 & - & Fop2 [154] & - \\
\hline & phaseoli race 4 & $\begin{array}{l}\text { LG10 [113] } \\
\text { LG3 [113] } \\
\text { LG11 [113] }\end{array}$ & $\begin{array}{l}- \\
- \\
-\end{array}$ & $\begin{array}{c}\text { U20.750 } \\
\text { (1.0) [113] } \\
-\end{array}$ \\
\hline & phaseoli race 6 & $\begin{array}{l}\operatorname{chr} 5 \text { [119] } \\
\text { chr7 [119] } \\
\text { chr8 [119] }\end{array}$ & $\begin{array}{l}\text { Phvul.004G000800, } \\
.004 G 006800, \mathrm{ng} ; \\
.005 \mathrm{G} 043100, \mathrm{ng} ; \\
\mathrm{ng}, .007 \mathrm{G} 270000 \\
\text { and .007G269900, } \\
\text { 007G270500; } \\
.008 \mathrm{G} 196600[119]\end{array}$ & $\begin{array}{c}\text { DART03480 (0.0), } \\
\text { SNP01469 (0.0) and } \\
\text { SNP01487 (0.0) [119]; } \\
\text { DART04561 (0.0), } \\
\text { SNP02051 (0.0) [119]; } \\
\text { SNP03304 (0.0), } \\
\text { SNP03305 (0.0) and } \\
\text { SNP03306 (0.0) [119]; } \\
\text { DART07926 (0.0) [119] }\end{array}$ \\
\hline Alfalfa & medicaginis & - & $F W_{1}, F W_{2}[164]$ & - \\
\hline
\end{tabular}

(1) correspondence between LG and the chromosomes nomenclature on pea genome v1a [178]; ${ }^{(2)}$ dominant/recessive nature is not known; ${ }^{(3)}$ genetic distance (cM) of the marker from the gene/QTL in parentheses; - no information available; ng: no candidate gene associated on gene annotation for P. vulgaris genome v2.1. 


\subsection{Gene Regulation Upon Legume Fo Infection}

A transcriptional profiling during plant-pathogen interaction allows identifying both candidate resistance genes from the plant and genes involved in disease processes from the pathogen.

Upregulation of genes involved in sucrose synthase [128,179-181] and genes involved in flavonoid biosynthesis $[179,182-185]$ were the most commonly detected in legume resistant accessions upon Fo infection. Among the genes involved in flavonoid biosynthesis, the chalcone synthase gene was described as essential for chickpea resistance against Fo f. sp. ciceris race 1 and $4[182,183]$ and in soybean Fo resistance [185]. Other genes, involved in ROS production, hormonal (ethylene and salicylic acid) signaling and biosynthesis, and pathogenesis-related (PR) genes were also frequently identified as candidate resistance genes $[144,181,183,185]$. Serine hydroxylmethyltransferase was also upregulated during Fo f. sp. ciceris race 1 and 5 infection $[180,186]$, suggesting that it has a role in Fo resistance. Furthermore, genes involved in lignin biosynthesis, important for cell wall reinforcement during Fo attacks (Section 4.2) were also upregulated in chickpea and soybean resistant accessions $[144,185]$. The expression of genes involved in the metabolism of phenolic compounds, previously identified as a barrier to fungus progression (Section 4.2), was also detected by a transcriptomic approach [185].

Several candidate resistance genes were identified in plants by transcriptomic approaches and can complement the previously described genetic insights for the breeding of $F o$-resistant crops. However, functional studies are still missing to validate their role during plant-pathogen interaction.

Understanding the two parts of the plant-pathogen interaction is important to completely unravel the molecular basis of resistance. However, in most of the previous legume-Fo interaction transcriptomic studies, only comparisons between plant transcripts were included due to low fungal transcript detection. The identification of Fo effector genes controlling pathogen host colonization must be considered in transcriptomic studies focused on the identification of differentially expressed genes from the Fo side and integrated with comparative Fo genomics studies.

\subsubsection{Fusarium oxysporum Effector Genes}

The identification of effector genes among Fo ff. spp. infecting legume species was achieved following different approaches. The most common was an in silico approach by comparative genomics through the sequencing of putative effector genes and subsequent comparison with homologous sequences from the Fusarium genome $[20,187]$. Nevertheless, the most reliable approach is the in planta approach, analyzing the upregulated effector transcripts after plant infection with $F_{0}[136,182,188-190]$. Effector genes already identified in some of the $F o$ ff. spp. and races infecting legume species are shown in Table 5. Secreten in xylem (SIX) genes, whose products are small effector proteins secreted during Fo colonization, are among the most important Fo effectors, and they have been also detected among different Fo ff. spp. and races infecting legumes. Although different SIX have been identified among Fo f. sp. pisi, phaseoli and medicaginis, none of them were present in all the isolates. FTF1 (Fusarium transcription factor 1) is another well-known Fo effector, which has been, for now, only described in Fo f. sp. phaseoli race $6[188,189]$. Among all the Fo effectors identified, only FTF1 and the paralog FTF2 were functionally validated by Fo f. sp. phaseoli RNAi knockdown mutants in common bean [189]. Results showed in the mutants a colonization pattern similar to the weak virulent strains in common beans, confirming FTF1 as a key regulator in Fo f. sp. phaseoli virulence [189]. 
Table 5. Known effector genes among Fo ff. spp. and races infecting legumes.

\begin{tabular}{cc}
\hline Fo f. sp. & Effector Genes \\
\hline pisi race 1 & SIX7, SIX10, SIX11, SIX12 and SIX14 [187] \\
\hline pisi race 2 & SIX13, SIX14 and CRX2 [187] \\
\hline pisi race 5 & SIX13 [187] \\
\hline ciceris race 1, 2 and 4 & chs7 (chitin synthase chaperonin) and Fow1 (mitochondrial carrier protein) [182] \\
\hline phaseoli race 4 & SIX6, SIX8 and SIX11 [187] \\
\hline phaseoli race 6 & SIX1 and SIX6 [136]; \\
medicaginis & FTF1 [188,189] and FTF2 [189] \\
\hline & $\begin{array}{c}\text { SIX1 [20], SIX8, SIX9 and SIX13 [20,190]; } \\
\text { secreted proteins encoding a lysin motif implicated in chitin binding and } \\
\text { proteases and peptidases involved in oxidative stress [190] }\end{array}$ \\
\hline
\end{tabular}

Although several candidate effector genes have been identified in Fo ff. spp. infecting legumes and most of them are widely known as being required for Fo pathogenicity in other ff. spp., it is important to reinforce the idea that functional validation of these genes is needed to confirm their contribution to virulence. For that, effector knockdown Fo strains can be generated or the effector genes can be directly expressed in planta via Agrobacterium-mediated infiltration to detect an $R$ (resistance) gene interaction or effector-induced necrosis [191]. If Fo effector genes are known, new $R$ genes could be identified.

\subsection{Conventional Breeding}

The development of legume resistant cultivars against Fo infection with an interesting agronomic potential is the main goal of any breeding program for Fusarium wilt resistance. The search and identification of resistant sources (Section 4.1.1) is the first step in any classical breeding program for Fusarium wilt resistance and has also been the case among several legume species programs.

Once the source of resistance is identified, the introgression of the genomic regions conferring resistance to Fusarium wilt into non-resistant elite genotypes can be obtained by a complex crossing selection scheme. In chickpea, single crosses between Desi-type parents carrying Fo resistance, with Kabuli-type parents, characterized by their large seed size and seed quality, have been successfully adopted in Fusarium wilt resistance breeding programs [192]. These hybridizations can also involve three-way crosses, or multiple crosses with more parents depending on the breeding goals complexity [193]. When information is available on the genetic basis of resistance, more directed approaches can be applied. For instance, when resistance is conferred by a single gene such as in chickpea against Fo f. sp. ciceris race 5 (see Section 4.3.1 for other examples), backcross breeding is commonly used to introgress resistance into well-adapted varieties [19,194]. Moreover, in chickpea, a combination of bulk and pedigree methods is often used to handle selection among the segregating generations [194]. This is the case of the chickpea breeding program in Tunisia (INRAT/CRRGC) with ICARDA contribution for tolerance/resistance to both Ascochyta blight and Fusarium wilt diseases [195].

The previously described conventional breeding approaches to obtain legume resistant varieties against Fo are time-consuming and not very efficient in complex resistance traits. To increase the efficiency and speed of breeding programs, precision breeding approaches, based on molecular innovations, have been developed and applied also for Fo-resistant legume varieties development.

\subsection{Precision Breeding Aprroaches}

The use of molecular markers closely linked to genes or QTLs controlling Fusarium wilt resistance allows a faster and more precise breeding. In Table 4, a compilation of the different types of molecular 
markers tightly linked with the legume genes of Fo resistance (previously described in Section 4.3), which could be useful for marker-assisted selection (MAS), is presented.

In chickpea, there are some examples of the use of MAS to support efficient and precise breeding. The SSR markers TR19, TA194 and TA660, polymorphic between the parental lines, were already used for foreground selection by marker-assisted backcrossing to introgress foc 1 in an elite chickpea cultivar [173]. Marker-assisted introgression using two other SSR markers in chickpea LG2, TA110 and TA37, was also used to transfer foc-2 to the background of an elite cultivar [174]. Among the several markers identified flanking the Fo f. sp. ciceris race 5 resistance gene, TA59 was used to develop near-isogenic lines resistant to Fo f. sp. ciceris race 5 [196].

Despite these examples, the use of molecular markers to assist breeding has not been widely adopted in legume breeding programs for Fusarium wilt resistance. Different causes can be attributable to the origin of this problem, but the large genetic distance between markers and the resistance genes/QTLs can be an important factor. Most of the legume markers presented in Table 4 are not tightly linked to the resistance genes/QTLs against Fo. High cM distances were often identified, which makes difficult their use in precision breeding. In lentil, for example, all the markers linked to resistance against $F o$ f. sp. lentis range between 3.5 and $10.8 \mathrm{cM}$, a considerable distance between the marker and the resistance gene [155,156]. Furthermore, not all the markers are ideal for MAS: namely U693a [153], OPJ20 600 [157,169] and OP-KI5900 [155], involved in resistance to Fo f. sp. pisi race 5, Fo f. sp. ciceris race 0 and Fo f. sp. lentis, respectively, are RAPD markers with limitations in reproducibility and detection of allelic variants among heterozygotes [197]. Finally, although some markers have been described as associated with the resistance trait, the distance between the marker and the gene/QTL is not always known.

A good example of promising markers are the ones involved in Fo f. sp. phaseoli race 6 resistance in common bean [119]. The associated detected SNP markers are within candidate genes, being very promising to support marker-assisted breeding in common bean if converted into breeding-friendly markers.

Although MAS is one of the most well-known approaches to convert conventional breeding into efficient precision breeding, innovative strategies as effector-driven breeding should be also considered. Generally, effectors' perception by resistance proteins triggers the host immune response [198]. Using effectors as a tool for precision breeding, new resistance genes can be more quickly and accurately identified [199].

This strategy was first applied for the hemibiotrophic Phytophthora infestans (Mont.) de Bary in potato breeding, and along the years, a catalog of $R$ (resistance from the host) genes and Avr (avirulence genes from the pathogen) genes was developed, allowing the study of their interaction directly by breeders [199]. In tomato, the effector Avr2 (SIX3) required for Fo f. sp. lycopersici virulence was also identified as involved in immunity triggering in plants carrying the $I-2$ resistance gene [200]. In the same work, Nicotiana benthamiana Domin leaves were agro-infiltrated with Avr2 and I-2. No hypersensitive reaction (HR) was observed at the regions expressing only one of the genes, but a HR occurred at the both genes' overlapping zone, revealing that both genes are required for the response forming a gene-for-gene pair [200]. This type of information reveals that in addition to the utilization of molecular markers for MAS, effectors can be also considered for future precision breeding by identifying promising $R$ genes (matching Avr genes), which could be exploited in future breeding for resistance against Fusarium wilt.

Further research on this topic is needed to unravel the interactions between the already identified Avr genes and new candidate resistance genes for Fo resistance in legumes. If the studied legume species can be infected by more than one Fo ff. spp. (Section 2), effectors from the different Fo ff. spp. should be considered, enabling the detection of important $R$ genes for several legume species. Although effector breeding has not yet been explored for Fo resistance in legumes, several effectors were already identified among Fo ff. spp. infecting legumes (Section 4.4.1) and can be explored for this purpose. 
Although not yet frequent in legume research, the integration of conventional breeding approaches with modern and efficient gene editing tools may promote a faster development of pathogen resistance plants, for instance, by knocking down "susceptibility genes" [201]. Gene editing tools such as CRISPR-Cas9 were already optimized and successfully used in legume species, for example, the study of the function of genes involved in small RNA processing or genes controlling symbiotic nitrogen fixation [202-204].

\section{Conclusions and Future Prospects}

Fusarium wilt caused by the soil-borne pathogen Fusarium oxysporum promotes severe damages to legume crop productivity [20]. The ability to remain in the soil for many years in the absence of a host [4] makes its eradication a difficult task. Furthermore, the existence of different $F o$ ff. spp. races and pathotypes infecting legumes makes the disease management even more complex. Effective management of Fusarium wilt in legumes can only be achieved combining different disease management strategies [16]. Although the role of rhizosphere microbiota in the suppression of soil-borne pathogens, due to an early triggering of plant defense responses, has been showing promising results, their effectiveness in Fusarium wilt control in legumes namely in field conditions still needs more research. Crop rotation, another important agricultural practice in disease control, also requires more investigation. Although labelled as a specialist pathogen for a long time, Fo ff. spp. can have a broader host range, infecting more than one legume species at the same time. Clarification of $F o$ ff. spp.'s host range is still needed to achieve accurate disease management, namely at the crop rotation level.

In addition to all the above, the use of resistant cultivars has been widely recognized as the most effective method for soil-borne diseases control [27]. The different approaches addressed in this review revealed significant achievements and progresses in breeding for Fusarium wilt resistance in legumes.

Besides the major legume species, where major constraints are more evident, it is also important to encourage research on resistance against Fusarium wilt on the commonly labelled "underused" crops, whose knowledge can bring important insights to improve other legume crops. An example is the case of the underused grass pea (Lathyrus sativus L.), phylogenetically closely related to pea and known for its remarkable resilience against pests and diseases. This species has proven already its potential as a resistance source for other legume fungi, although it is considered weakly specialized [205,206], which can be exploited in the breeding of related major legume crops [207]. However, it has been poorly explored for Fo resistance. Adding this resilient closely related plant species to the search for resistance against some of the Fo ff. spp. infecting legumes would be a good starting point to unravel if this legume can be or not considered for Fusarium wilt resistance breeding in other legume crops' improvement.

Author Contributions: Writing—original draft, A.M.S.; writing—review and editing, S.d.S.A., D.R. and M.C.V.P.; funding acquisition, M.C.V.P. All authors have read and agreed to the published version of the manuscript.

Funding: This research was funded by Fundação para a Ciência e Tecnologia (FCT), Portugal through grant PD/BD/114118/2016 (A.M.S.), the PhD holder contract (DL57) (S.d.S.A.), the IF/01337/2014 FCT Investigator contract (M.C.V.P.), the research unit GREEN-IT (UID/04551/2020), the QuaLaty project (PTDC/AGR-TEC/0992/2014) and the Spanish Research Agency (AEI) project AGL2017-82907-R.

Conflicts of Interest: The authors declare no conflict of interest.

\section{References}

1. Moss, M.O.; Smith, J.E. The Applied Mycology of Fusarium; Cambridge University Press: Cambridge, UK, 1984.

2. Ma, L.-J.; Geiser, D.M.; Proctor, R.H.; Rooney, A.P.; O’Donnell, K.; Trail, F.; Gardiner, D.M.; Manners, J.M.; Kazan, K. Fusarium pathogenomics. Annu. Rev. Microbiol. 2013, 67, 399-416. [CrossRef]

3. Di Pietro, A.; Madrid, M.P.; Caracuel, Z.; Delgado-Jarana, J.; Roncero, M.I.G. Fusarium oxysporum: Exploring the molecular arsenal of a vascular wilt fungus. Mol. Plant Pathol. 2003, 4, 315-325. [CrossRef]

4. Agrios, G.N. Plant Pathology; Elsevier Academic Press: Cambridge, MA, USA, 2005. 
5. Michielse, C.B.; Rep, M. Pathogen profile update: Fusarium oxysporum. Mol. Plant Pathol. 2009, 10, $311-324$. [CrossRef]

6. Dean, R.; Van Kan, J.A.L.; Pretorius, Z.A.; Hammond-Kosack, K.E.; Di Pietro, A.; Spanu, P.D.; Rudd, J.J.; Dickman, M.; Kahmann, R.; Ellis, J.; et al. The Top 10 fungal pathogens in molecular plant pathology. Mol. Plant Pathol. 2012, 13, 414-430. [CrossRef]

7. European Commission, Commission Implementing Regulation (EU) 2019/2072 of 28 November 2019 establishing uniform conditions for the implementation of Regulation (EU) 2016/2031 of the European Parliament and the Council, as regards protective measures against pests of plants, a. Off. J. Eur. Union 2019, 62, 1-319.

8. McDonald, B.A.; Linde, C. Pathogen population genetics, evolutionary potential, and durable resistance. Annu. Rev. Phytopathol. 2002, 40, 349-379. [CrossRef]

9. Roncero, M.I.G.; Hera, C.; Ruiz-Rubio, M.; Maceira, F.I.G.; Madrid, M.P.; Caracuel, Z.; Calero, F.; Delgado-Jarana, J.; Roldán-Rodríguez, R.; Martínez-Rocha, A.L.; et al. Fusarium as a model for studying virulence in soilborne plant pathogens. Physiol. Mol. Plant Pathol. 2003, 62, 87-98. [CrossRef]

10. Nelson, E.B. Exudate molecules initiating fungal responses to seeds and roots. In The Rhizosphere and Plant Growth; Springer: Dordrecht, The Netherlands, 1991; pp. 197-209.

11. Turrà, D.; El Ghalid, M.; Rossi, F.; Di Pietro, A. Fungal pathogen uses sex pheromone receptor for chemotropic sensing of host plant signals. Nature 2015, 527, 521-524. [CrossRef]

12. Perez-Nadales, E.; Di Pietro, A. The membrane mucin Msb2 regulates invasive growth and plant infection in Fusarium oxysporum. Plant Cell 2011, 23, 1171-1185. [CrossRef]

13. Perez-Nadales, E.; Almeida Nogueira, M.F.; Baldin, C.; Castanheira, S.; El Ghalid, M.; Grund, E.; Lengeler, K.; Marchegiani, E.; Mehrotra, P.V.; Moretti, M.; et al. Fungal model systems and the elucidation of pathogenicity determinants. Fungal Genet. Biol. 2014, 70, 42-67. [CrossRef]

14. Bishop, C.D.; Cooper, R.M. An ultrastructural study of vascular colonization in three vascular wilt diseases I. Colonization of susceptible cultivars. Physiol. Plant Pathol. 1983, 23, 323-343. [CrossRef]

15. Beckman, C.H. The nature of wilt diseases of plants; APS Press: St. Paul, MN, USA, 1987.

16. Jiménez-Díaz, R.M.; Castillo, P.; Jiménez-Gasco, M.d.M.; Landa, B.B.; Navas-Cortés, J.A. Fusarium wilt of chickpeas: Biology, ecology and management. Crop Prot. 2015, 73, 16-27. [CrossRef]

17. Vance, C.P.; Graham, P.H.; Allan, D.L. Biological Nitrogen Fixation: Phosphorus-A Critical Future Need? In Nitrogen Fixation: From Molecules to Crop Productivity; Pedrosa, F.O., Hungria, M., Yates, G., Newton, W.E., Eds.; Springer: Dordrecht, The Netherlands, 2000; pp. 509-514.

18. Azooz, M.M.; Ahmad, P. Legumes under Environmental Stress: Yield, Improvement and Adaptations; Wiley-Blackwell: Hoboken, NJ, USA, 2015.

19. Rubiales, D.; Fondevilla, S.; Chen, W.; Gentzbittel, L.; Higgins, T.J.V.; Castillejo, M.A.; Singh, K.B.; Rispail, N. Achievements and challenges in legume breeding for pest and disease resistance. CRC Crit. Rev. Plant Sci. 2015, 34, 195-236. [CrossRef]

20. Williams, A.H.; Sharma, M.; Thatcher, L.F.; Azam, S.; Hane, J.K.; Sperschneider, J.; Kidd, B.N.; Anderson, J.P.; Ghosh, R.; Garg, G.; et al. Comparative genomics and prediction of conditionally dispensable sequences in legume-infecting Fusarium oxysporum formae speciales facilitates identification of candidate effectors. BMC Genom. 2016, 17, 191. [CrossRef]

21. Haglund, W.A.; Kraft, J.M. Fusarium wilt. In Compendium of Pea Diseases and Pests; Kraft, J.M., Pfleger, F.L., Eds.; APS Press: St. Paul, MN, USA, 2001; pp. 14-16.

22. FAOSTAT. Food and Agriculture Organization of the United Nations, FAOSTAT. Available online: http: //www.fao.org/faostat/en/\#data/QC (accessed on 21 May 2020).

23. Alves-Santos, F.M.; Cordeiro-Rodrigues, L.; Sayagués, J.M.; Martín-Domínguez, R.; Garcia-Benavides, P.; Crespo, M.C.; Díaz-Mínguez, J.M.; Eslava, A.P. Pathogenicity and race characterization of Fusarium oxysporum f. sp. phaseoli isolates from Spain and Greece. Plant Pathol. 2002, 51, 605-611. [CrossRef]

24. Navas-Cortés, J.A.; Hau, B.; Jiménez-Díaz, R.M. Yield loss in chickpeas in relation to development of Fusarium wilt epidemics. Phytopathology 2000, 90, 1269-1278. [CrossRef]

25. Taylor, P.; Lindbeck, K.; Chen, W.; Ford, R. Lentil Diseases. In Lentil; Springer: Dordrecht, The Netherlands, 2007; pp. 291-313. 
26. Ramírez-Suero, M.; Khanshour, A.; Martinez, Y.; Rickauer, M. A study on the susceptibility of the model legume plant Medicago truncatula to the soil-borne pathogen Fusarium oxysporum. Eur. J. Plant Pathol. 2010, 126, 517-530. [CrossRef]

27. Panth, M.; Hassler, S.C.; Baysal-Gurel, F. Methods for management of soilborne diseases in crop production. Agriculture 2020, 10, 16. [CrossRef]

28. Armstrong, G.M.; Armstrong, J.K. Fusarium: Diseases, biology, and taxonomy. In Formae Speciales and Races of Fusarium Oxysporum Causing Wilt Diseases; Nelson, P.E., Toussoun, T.A., Cook, R., Eds.; The Pennsylvania State University Press: University Park, PA, USA, 1981; pp. 391-399.

29. Edel-Hermann, V.; Lecomte, C. Current status of Fusarium oxysporum formae speciales and races. Phytopathology 2019, 109, 512-530. [CrossRef]

30. Infantino, A.; Kharrat, M.; Riccioni, L.; Coyne, C.J.; Mcphee, K.E.; Grünwald, N.J. Screening techniques and sources of resistance to root diseases in cool season food legumes. Euphytica 2006, 147, 201-221. [CrossRef]

31. Demers, J.E.; Garzón, C.D.; Jiménez-Gasco, M.d.M. Striking genetic similarity between races of Fusarium oxysporum f. sp. ciceris confirms a monophyletic origin and clonal evolution of the chickpea vascular wilt pathogen. Eur. J. Plant Pathol. 2014, 139, 309-324. [CrossRef]

32. Pottorff, M.; Wanamaker, S.; Ma, Y.Q.; Ehlers, J.D.; Roberts, P.A.; Close, T.J. Genetic and physical mapping of candidate genes for resistance to Fusarium oxysporum f.sp. tracheiphilum race 3 in cowpea [Vigna unguiculata (L.) Walp]. PLoS ONE 2012, 7, e41600. [CrossRef]

33. Jendoubi, W.; Bouhadida, M.; Boukteb, A.; Béji, M.; Kharrat, M. Fusarium Wilt Affecting Chickpea Crop. Agriculture 2017, 7, 23. [CrossRef]

34. Armstrong, G.M.; Armstrong, J.K. Lupinus species-Common hosts for wilt Fusaria from alfalfa, bean cassia, cowpea, lupine and U.S. cotton. Phytopathology 1964, 54, 1232-1234. [CrossRef]

35. Lamberts, H. Broadening the basis for the breeding of yellow sweet lupine. Euphytica 1955, 4, 97-196. [CrossRef]

36. Venuto, B.C.; Smith, R.R.; Grau, C.R. Virulence, legume hostspecificity, and genetic relatedness of isolates of Fusarium oxysporum from red clover. Plant Dis. 1995, 79, 406-410. [CrossRef]

37. Grajal-Martín, M.J.; Simon, C.J.; Muehlbauer, F.J. Use of Random Ampfified Polymorphic DNA (RAPD) to characterize race 2 of Fusarium oxysporum f. sp. pisi. Mol. Plant Pathol. 1993, 83, 612-614. [CrossRef]

38. Haglund, W.A.; Kraft, J.M. Fusarium oxysporum f. sp. pisi, race 6: Occurrence and distribution. Phytopathology 1979, 69, 818. [CrossRef]

39. Haware, M.P.; Nene, Y.L. Races of Fusarium oxysporum f. sp. ciceri. Plant Dis. 1982, 66, 809-810. [CrossRef]

40. Jiménez-Díaz, R.M.; Basallote-Ureba, M.J.; Rapoport, H. Colonization and pathogenesis in chickpeas infected by races of Fusarium oxysporum f. sp. ciceri. In Vascular Wilt Diseases of Plants; Springer: Berlin/Heidelberg, Germany, 1989; pp. 113-121.

41. Jiménez-Díaz, R.M.; Alcala, A.; Hervas, A.; Trapero Casas, J.L. Pathogenic variability and host resistance in the Fusarium oxysporum f.sp. ciceris/Cicer arietinum pathosystem. Hod. Rosl. Aklim. i Nasienn. 1993, 37, 87-94.

42. Gordon, W.L. Pathogenic strains of Fusarium oxysporum. Can. J. Bot. 1965, 43, 1309-1318. [CrossRef]

43. Pouralibaba, H.R.; Rubiales, D.; Fondevilla, S. Identification of pathotypes in Fusarium oxysporum f. sp. lentis. Eur. J. Plant Pathol. 2016, 144, 539-549. [CrossRef]

44. Hiremani, N.S.; Dubey, S.C. Race profiling of Fusarium oxysporum f. sp. lentis causing wilt in lentil. Crop Prot. 2018, 108, 23-30. [CrossRef]

45. Hare, W.W. A new race of Fusarium causing wilt of cowpea. Phytopathology 1953, 43, 291.

46. Smith, S.N.; Helms, D.M.; Temple, S.R.; Frate, C. The distribution of Fusarium wilt of blackeyed cowpeas within California caused by Fusarium oxysporum f. sp. tracheiphilum race 4. Plant Dis. 1999, 83, 694. [CrossRef]

47. Armstrong, G.M.; Armstrong, J.K. A wilt of soybean caused by a new form of Fusarium oxysporum. Phytopathology 1965, 55, 237-239.

48. Brayford, D. Fusarium oxysporum f. sp. medicaginis. IMI Descr. Fungi Bact. 1996, 1268, 1-2.

49. Synder, W.C.; Hansen, H.N. The species concept in Fusarium. Am. J. Bot. 1940, 27, 64-67.

50. Yu, T.F.; Fang, C.T. Fusarium diseases of broad beans. III. Root-rot and wilt of broad beans caused by two new forms of Fusarium. Phytopathology 1948, 38, 587-594.

51. Wunsch, M.J.; Baker, A.H.; Kalb, D.W.; Bergstrom, G.C. Characterization of Fusarium oxysporum f. sp. loti Forma Specialis nov., a Monophyletic Pathogen Causing Vascular Wilt of Birdsfoot Trefoil. Plant Dis. 2009, 93, 58-66. [CrossRef] 
52. De Curtis, F.; Palmieri, D.; Vitullo, D.; Lima, G. First report of Fusarium oxysporum f.sp. pisi as causal agent of root and crown rot on chickpea (Cicer arietinum) in Southern Italy. Plant Dis. 2014, 98, 995. [CrossRef]

53. Sumner, D.R.; Minton, N.A. Interaction of Fusarium wilt and nematodes in Cobb soybean. Plant Dis. 1987, $71,20-23$.

54. Dhingra, O.D.; Netto, R.A.C. Reservoir and non-reservoir hosts of bean-wilt pathogen, Fusarium oxysporum $\mathrm{f}$. sp. phaseoli. J. Phytopathol. 2001, 149, 463-467. [CrossRef]

55. Yadeta, K.A.; Thomma, B.P.H.J. The xylem as battleground for plant hosts and vascular wilt pathogens. Front. Plant Sci. 2013, 4, 97. [CrossRef]

56. Gullino, M.L.; Camponogara, A.; Gasparrini, G.; Rizzo, V.; Clini, C.; Garibaldi, A. Replacing methyl bromide for soil disinfection: The Italian experience and implications for other countries. Plant Dis. 2003, 87, 1012-1021. [CrossRef]

57. Ebbels, D.L. Effect of soil fumigants on Fusarium wilt and nodulation of peas (Pisum sativum L.). Ann. Appl. Biol. 1967, 60, 391-398. [CrossRef]

58. Zhao, J.; Mei, Z.; Zhang, X.; Xue, C.; Zhang, C.; Ma, T.; Zhang, S. Suppression of Fusarium wilt of cucumber by ammonia gas fumigation via reduction of Fusarium population in the field. Sci. Rep. 2017, 7, 1-8. [CrossRef]

59. Barzman, M.; Bàrberi, P.; Birch, A.N.E.; Boonekamp, P.; Dachbrodt-Saaydeh, S.; Graf, B.; Hommel, B.; Jensen, J.E.; Kiss, J.; Kudsk, P.; et al. Eight principles of integrated pest management. Agron. Sustain. Dev. 2015, 35, 1199-1215. [CrossRef]

60. El-Hassan, S.A.; Gowen, S.R.; Pembroke, B. Use of Trichoderma hamatum for biocontrol of lentil vascular wilt disease: Efficacy, mechanisms of interaction and future prospects. J. Plant Prot. Res. 2013, 53, $12-26$. [CrossRef]

61. Carvalho, D.D.C.; de Mello, S.C.M.; Martins, I.; Lobo, M. Biological control of Fusarium wilt on common beans by in-furrow application of Trichoderma harzianum. Trop. Plant Pathol. 2015, 40, 375-381. [CrossRef]

62. Hervás, A.; Landa, B.; Datnoff, L.E.; Jiménez-Díaz, R.M. Effects of commercial and indigenous microorganisms on Fusarium wilt development in chickpea. Biol. Control 1998, 13, 166-176. [CrossRef]

63. Landa, B.B.; Navas-Cortés, J.A.; Hervás, A.; Jiménez-Díaz, R.M. Influence of temperature and inoculum density of Fusarium oxysporum f. sp. ciceris on suppression of Fusarium wilt of chickpea by rhizosphere bacteria. Phytopathology 2001, 91, 807. [CrossRef]

64. Bubici, G. Streptomyces spp. as biocontrol agents against Fusarium species. CAB Rev. Perspect. Agric. Vet. Sci. Nutr. Nat. Resour. 2018, 13, 1-15. [CrossRef]

65. Bubici, G.; Kaushal, M.; Prigigallo, M.I.; Cabanás, C.G.L.; Mercado-Blanco, J. Biological control agents against Fusarium wilt of banana. Front. Microbiol. 2019, 10, 616. [CrossRef]

66. Anusha, B.G.; Gopalakrishnan, S.; Naik, M.K.; Sharma, M. Evaluation of Streptomyces spp. and Bacillus spp. for biocontrol of Fusarium wilt in chickpea (Cicer arietinum L.). Arch. Phytopathol. Plant Prot. 2019, 52, 417-442. [CrossRef]

67. Palmieri, D.; Vitullo, D.; De Curtis, F.; Lima, G. A microbial consortium in the rhizosphere as a new biocontrol approach against fusarium decline of chickpea. Plant Soil 2017, 412, 425-439. [CrossRef]

68. Abdul Wahid, O.A. Improving control of Fusarium wilt of leguminous plants by combined application of biocontrol agents. Phytopathol. Mediterr. 2006, 45, 231-237. [CrossRef]

69. Bapat, S.; Shah, A.K. Biological control of fusarial wilt of pigeon pea by Bacillus brevis. Can. J. Microbiol. 2000, 46, 125-132. [CrossRef]

70. Das, K.; Prasanna, R.; Saxena, A.K. Rhizobia: A potential biocontrol agent for soilborne fungal pathogens. Folia Microbiol. 2017, 62, 425-435. [CrossRef]

71. Demir, S.; Akkopru, A. Using of arbuscular mycorrhizal fungi (AMF) for biocontrol of soil-borne fungal plant pathogens. In Biological Control of Plant Diseases; Chincholkar, S.B., Mukerji, K.G., Eds.; Haworth Press: Philadelphia, PA, USA, 2007; pp. 17-37.

72. Singh, P.K.; Singh, M.; Vyas, D. Biocontrol of fusarium wilt of chickpea using arbuscular mycorrhizal fungi and rhizobium leguminosorum biovar. Caryologia 2010, 63, 349-353. [CrossRef]

73. Arfaoui, A.; Sifi, B.; Boudabous, A.; El Hadrami, I.; Chérif, M. Identification of Rhizobium isolates possessing antagonistic activity against Fusarium oxysporum f. sp. ciceris, the causal agent of Fusarium wilt of chickpea. J. Plant Pathol. 2006, 88, 67-75. [CrossRef]

74. Sajeena, A.; Nair, D.S.; Sreepavan, K. Non-pathogenic Fusarium oxysporm as a biocontrol agent. Indian Phytopathol. 2020, 73, 177-183. [CrossRef] 
75. Benhamou, N.; Garand, C. Cytological analysis of defense-related mechanisms induced in pea root tissues in response to colonization by nonpathogenic Fusarium oxysporum Fo47. Phytopathology 2001, 91, 730-740. [CrossRef]

76. Landa, B.B.; Navas-Cortés, J.A.; Jiménez-Díaz, R.M. Integrated management of Fusarium wilt of chickpea with sowing date, host resistance, and biological control. Phytopathology 2004, 94, 946-960. [CrossRef]

77. Gordon, T.R.; Martyn, R.D. The evolutionary biology of Fusarium oxysporum. Annu. Rev. Phytopathol. 1997, 35, 111-128. [CrossRef]

78. Pande, S.; Rao, J.N.; Sharma, M. The plant pathology journal establishment of the chickpea wilt pathogen Fusarium oxysporum f. sp. ciceris in the soil through seed transmission. Plant Pathol. J. 2007, 23, 3-6.

79. de Sousa, M.V.; Machado, J.d.C.; Simmons, H.E.; Munkvold, G.P. Real-time quantitative PCR assays for the rapid detection and quantification of Fusarium oxysporum f. sp. phaseoli in Phaseolus vulgaris (common bean) seeds. Plant Pathol. 2015, 64, 478-488. [CrossRef]

80. Haware, M.P. Diseases of chickpea. In The Pathology of Food and Pasture Legumes; Allen, D.J., Lenné, J.M., Eds.; CAB International: Wallingford, UK, 1998; pp. 473-561.

81. Chauhan, Y.S.; Nene, Y.L.; Johansen, C.; Haware, M.P.; Saxena, N.P.; Sardar, S.; Sharma, S.B.; Sahrawat, K.L.; Burford, J.R.; Rupela, O.P.; et al. Effects of Soil Solarization on Pigeonpea and Chickpea; International Crops Research Institute for the Semi-Arid Tropics: Patancheru, India, 1988.

82. Larkin, R.P. Green manures and plant disease management. CAB Rev. Perspect. Agric. Vet. Sci. Nutr. Nat. Resour. 2013, 8. [CrossRef]

83. Prasad, P.; Kumar, J. Management of fusarium wilt of chickpea using brassicas as biofumigants. Legum. Res. 2017, 40, 178-182. [CrossRef]

84. Gordon, T.R. Colonization of muskmelon and nonsusceptible crops by Fusarium oxysporum f. sp. melonis and other species of Fusarium. Phytopathology 1989, 79, 1095. [CrossRef]

85. Haware, M.P.; Nene, Y.L.; Natarajan, M. The survival of Fusarium oxysporum f. sp. ciceri in the soil in the absence of chickpea. Phytopathol. Mediterr. 1996, 35, 9-12.

86. Helbig, J.B.; Carroll, R.B. Dicotyledonous weeds as a source of Fusarium oxysporum pathogenic on soybean. Plant Dis. 1984, 68, 694-696. [CrossRef]

87. Jiménez-Fernández, D.; Montes-Borrego, M.; Jiménez-Díaz, R.M.; Navas-Cortés, J.A.; Landa, B.B. In planta and soil quantification of Fusarium oxysporum f. sp. ciceris and evaluation of fusarium wilt resistance in chickpea with a newly developed quantitative polymerase chain reaction assay. Phytopathology 2011, 101, 250-262. [CrossRef]

88. Sharma, K.D.; Rathour, R.; Kapila, R.K.; Paul, Y.S. Detection of pea wilt pathogen Fusarium oxysporum f. sp. pisi using DNA-based markers. J. Plant Biochem. Biotechnol. 2018, 27, 342-350. [CrossRef]

89. Pouralibaba, H.R.; Rubiales, D.; Fondevilla, S. Identification of resistance to Fusarium oxysporum f. sp. lentis in Spanish lentil germplasm. Eur. J. Plant Pathol. 2015, 143, 399-405. [CrossRef]

90. Bayaa, B.; Erskine, W.; Singh, M. Screening lentil for resistance to fusarium wilt: Methodology and sources of resistance. Euphytica 1997, 98, 69-74. [CrossRef]

91. Castillo, P.; Navas-Cortés, J.A.; Gomar-Tinoco, D.; Di Vito, M.; Jiménez-Díaz, R.M. Interactions between Meloidogyne artiellia, the cereal and legume root-knot nematode, and Fusarium oxysporum $\mathrm{f}$. sp. ciceris race 5 in chickpea. Phytopathology 2003, 93, 1513-1523. [CrossRef]

92. Castillo, P.; Mora-Rodríguez, M.P.; Navas-Cortés, J.A.; Jiménez-Díaz, R.M. Interactions of Pratylenchus thornei and Fusarium oxysporum f. sp. ciceris on chickpea. Phytopathology 1998, 88, 828-836. [CrossRef]

93. Krishna Rao, V.; Krishnappa, K. Interaction of Fusarium oxysporum f.sp. ciceri with Meloidogyne incognita on chickpea in two soil types. Indian Phytopathol. 1996, 49, 142-147.

94. Navas-Cortés, J.A.; Landa, B.B.; Rodríguez-López, J.; Jiménez-Díaz, R.M.; Castillo, P. Infection by Meloidogyne artiellia does not break down resistance to races $0,1 \mathrm{~A}$, and 2 of Fusarium oxysporum $\mathrm{f}$. sp. ciceris in chickpea genotypes. Phytopathology 2008, 98, 709-718. [CrossRef]

95. Haglund, W.A. A rapid method for inoculating pea seedlings with Fusarium oxysporum f. sp. pisi. Plant Dis. 1989, 73, 457. [CrossRef]

96. Eynck, C.; Koopmann, B.; von Tiedemann, A. Identification of Brassica accessions with enhanced resistance to Verticillium longisporum under controlled and field conditions. J. Plant Dis. Prot. 2009, 116, 63-72. [CrossRef] 
97. Landa, B.B.; Navas-Cortés, J.A.; del Mar Jiménez-Gasco, M.; Katan, J.; Retig, B.; Jiménez-Díaz, R.M. Temperature response of chickpea cultivars to races of Fusarium oxysporum f. sp. ciceris, causal agent of Fusarium wilt. Plant Dis. 2006, 90, 365-374. [CrossRef]

98. Haware, M.P.; Nene, Y.L.; Pundir, R.P.S.; Narayana Rao, J. Screening of world chickpea germplasm for resistance to fusarium wilt. Field Crop. Res. 1992, 30, 147-154. [CrossRef]

99. Jiménez-Díaz, R.M. Resistance in Kabuli chickpeas to Fusarium wilt. Plant Dis. 1991, 75, 914. [CrossRef]

100. Sharma, M.; Kiran Babu, T.; Gaur, P.M.; Ghosh, R.; Rameshwar, T.; Chaudhary, R.G.; Upadhyay, J.P.; Gupta, O.; Saxena, D.R.; Kaur, L.; et al. Identification and multi-environment validation of resistance to Fusarium oxysporum f. sp. ciceris in chickpea. Field Crop. Res. 2012, 135, 82-88. [CrossRef]

101. Sharma, M.; Ghosh, R.; Tarafdar, A.; Rathore, A.; Chobe, D.R.; Kumar, A.V.; Gaur, P.M.; Samineni, S.; Gupta, O.; Singh, N.P.; et al. Exploring the genetic cipher of chickpea (Cicer arietinum L.) through identification and multi-environment validation of resistant sources against Fusarium wilt (Fusarium oxysporum f. sp. ciceris). Front. Sustain. Food Syst. 2019, 3, 78. [CrossRef]

102. Mohammadi, N.; Puralibaba, H.; Goltapeh, E.M.; Ahari, A.B.; Sardrood, B.P. Advanced lentil lines screened for resistance to Fusarium oxysporum $\mathrm{f}$. sp. lentis under greenhouse and field conditions. Phytoparasitica 2012, 40, 69-76. [CrossRef]

103. Navas-Cortés, J.A.; Hau, B.; Jiménez-Díaz, R.M. Effect of sowing date, host cultivar, and race of Fusarium oxysporum f. sp. ciceris on development of Fusarium wilt of chickpea. Phytopathology 1998, 44, 1338-1346. [CrossRef]

104. Singh, M.; Rana, J.C.; Singh, B.; Kumar, S.; Saxena, D.R.; Saxena, A.; Rizvi, A.H.; Sarker, A. Comparative agronomic performance and reaction to Fusarium wilt of Lens culinaris $\times$ L. orientalis and L. culinaris $\times L$. ervoides derivatives. Front. Plant Sci. 2017, 8, 1162. [CrossRef]

105. Emberger, G.; Welty, R.E. Evaluation of virulence of Fusarium oxysporum f. sp. medicaginis and Fusarium wilt resistance in alfalfa. Plant Dis. 1983, 67, 94. [CrossRef]

106. McPhee, K.E.; Tullu, A.; Kraft, J.M.; Muehlbauer, F.J. Resistance to Fusarium wilt race 2 in the Pisum core collection. J. Am. Soc. Hortic. Sci. 1999, 124, 28-31. [CrossRef]

107. McPhee, K.E.; Inglis, D.A.; Gundersen, B.; Coyne, C.J. Mapping QTL for Fusarium wilt race 2 partial resistance in pea (Pisum sativum). Plant Breed. 2012, 131, 300-306. [CrossRef]

108. Stoilova, T.; Chavdarov, P. Evaluation of lentil germplasm for disease resistance to Fusarium wilt (Fusarium oxysporum f. sp. lentis). J. Cent. Eur. Agric. 2006, 7, 121-126.

109. Bani, M.; Rubiales, D.; Rispail, N. A detailed evaluation method to identify sources of quantitative resistance to Fusarium oxysporum f. sp. pisi race 2 within a Pisum spp. germplasm collection. Plant Pathol. 2012, 61, 532-542. [CrossRef]

110. Rispail, N.; Bani, M.; Rubiales, D. Resistance reaction of Medicago truncatula genotypes to Fusarium oxysporum: Effect of plant age, substrate and inoculation method. Crop Pasture Sci. 2015, 66, 506. [CrossRef]

111. Bayaa, B.; Erskine, W.; Hamdi, A. Evaluation of a wild lentil collection for resistance to vascular wilt. Genet. Resour. Crop Evol. 1995, 42, 231-235. [CrossRef]

112. Buruchara, R.A.; Camacho, L. Common bean reaction to Fusarium oxysporum f. sp. phaseoli, the cause of severe vascular wilt in Central Africa. J. Phytopathol. 2000, 148, 39-45. [CrossRef]

113. Fall, A.L.; Byrne, P.F.; Jung, G.; Coyne, D.P.; Brick, M.A.; Schwartz, H.F. Detection and mapping of a major locus for Fusarium wilt resistance in common bean. Crop Sci. 2001, 41, 1494. [CrossRef]

114. Rispail, N.; Rubiales, D. Identification of sources of quantitative resistance to Fusarium oxysporum f. sp. medicaginis in Medicago truncatula. Plant Dis. 2014, 98, 667-673. [CrossRef]

115. Charchart, M.; Kraft, J.M. Response of near-isogenic pea cultivars to infection by Fusarium oxysporum f. sp. pisi races 1 and 5. Can. J. Plant Sci. 1989, 69, 1335-1346.

116. Merzoug, A.; Belabid, L.; Youcef-Benkada, M.; Benfreha, F.; Bayaa, B. Pea Fusarium wilt races in Western Algeria. Plant Prot. Sci. 2014, 50, 70-77. [CrossRef]

117. Neumann, S.; Xue, A.G. Reactions of field pea cultivars to four races of Fusarium oxysporum f. sp. pisi. Can. J. Plant Sci. 2003, 83, 377-379. [CrossRef]

118. Arvayo-Ortiz, R.M.; Martin, E.; Acedo-Felix, E.; Gonzalez-Rios, H.; Vargas-Rosales, G. New lines of chickpea against Fusarium oxysporum f. sp. ciceris wilt. Am. J. Appl. Sci. 2012, 9, 686-693. [CrossRef] 
119. Leitão, S.T.; Malosetti, M.; Song, Q.; van Eeuwijk, F.; Rubiales, D.; Vaz Patto, M.C. Natural variation in Portuguese common bean germplasm reveals new sources of resistance against Fusarium oxysporum $\mathrm{f}$. sp. phaseoli and resistance-associated candidate genes. Phytopathology 2020, 110, 633-647. [CrossRef]

120. Altier, N.A.; Groth, J.V. Characterization of aggressiveness and vegetative compatibility diversity of Fusarium oxysporum associated with crown and root rot of birdsfoot trefoil. Lotus Newsl. 2005, 35, 59-74.

121. Lebeda, A.; Svabova, L.; Dostalova, R. Screening of peas for resistance to fusarium wilt and root rot (Fusarium oxysporum, Fusarium solani). In Mass Screening Techniques for Selecting Crops Resistant to Disease; Spencer, M., Lebeda, A., Eds.; FAO/IAEA: Vienna, Austria, 2010; pp. 189-196.

122. Zian, A.H.; El-Demardash, I.S.; El-Mouhamady, A.A.; El-Barougy, E. Studies the resistance of lupine for Fusarium oxysporum f. sp lupini) through molecular genetic technique. World Appl. Sci. J. 2013, 26, 1064-1069. [CrossRef]

123. Rispail, N.; Rubiales, D. Rapid and efficient estimation of pea resistance to the soil-borne pathogen Fusarium oxysporum by infrared imaging. Sensors 2015, 15, 3988-4000. [CrossRef]

124. Bishop, C.D.; Cooper, R.M. An ultrastructural study of root invasion in three vascular wilt diseases. Physiol. Plant Pathol. 1983, 22, 15-27. [CrossRef]

125. Bani, M.; Pérez-De-Luque, A.; Rubiales, D.; Rispail, N. Physical and chemical barriers in root tissues contribute to quantitative resistance to Fusarium oxysporum f. sp. pisi in pea. Front. Plant Sci. 2018, 9, 199. [CrossRef]

126. Tessier, B.J.; Mueller, W.C.; Morgham, A.T. Histopathology and ultrastructure of vascular-responses in peas resistant or susceptible to Fusarium oxysporum f. sp. pisi. Phytopathology 1990, 80, 756-764. [CrossRef]

127. Pouralibaba, H.R.; Pérez-de-Luque, A.; Rubiales, D. Histopathology of the infection on resistant and susceptible lentil accessions by two contrasting pathotypes of Fusarium oxysporum f. sp. lentis. Eur. J. Plant Pathol. 2017, 148, 53-63. [CrossRef]

128. Gupta, S.; Chakraborti, D.; Sengupta, A.; Basu, D.; Das, S. Primary metabolism of chickpea is the initial target of wound inducing early sensed Fusarium oxysporum f. sp. ciceri race I. PLoS ONE 2010, 5, e9030. [CrossRef]

129. Joshi, N.S.; Rao, K.S.; Subramanian, R.B. Anatomical and biochemical aspects of interaction between roots of chickpea and Fusarium oxysporum f. sp. ciceris race 2. Arch. Phytopathol. Plant Prot. 2012, 45, 1773-1789. [CrossRef]

130. Miranda, K.; Girard-Dias, W.; Attias, M.; De Souza, W.; Ramos, I.; Celular, U.; Meyer, H. Three dimensional reconstruction by electron microscopy in the life sciences: An introduction for cell and tissue biologists. Mol. Reprod. Dev. Mol. Reprod. Dev. 2015, 82, 530-547. [CrossRef]

131. Pereira, A.C.; Cruz, M.F.A.; Paula Júnior, T.J.; Rodrigues, F.A.; Carneiro, J.E.S.; Vieira, R.F.; Carneiro, P.C.S. Infection process of Fusarium oxysporum f. sp. phaseoli on resistant, intermediate and susceptible bean cultivars. Trop. Plant Pathol. 2013, 38, 323-328. [CrossRef]

132. Xue, R.; Wu, J.; Zhu, Z.; Wang, L.; Wang, X.; Wang, S.; Blair, M.W. Differentially expressed genes in resistant and susceptible common bean (Phaseolus vulgaris L.) genotypes in response to Fusarium oxysporum f. sp. phaseoli. PLoS ONE 2015, 10, e0127698. [CrossRef]

133. Jiménez-Fernández, D.; Landa, B.B.; Kang, S.; Jiménez-Díaz, R.M.; Navas-Cortés, J.A. Quantitative and microscopic assessment of compatible and incompatible interactions between chickpea cultivars and Fusarium oxysporum f. sp. ciceris races. PLoS ONE 2013, 8, e61360. [CrossRef]

134. Islam, M.N.; Nizam, S.; Verma, P.K. A highly efficient Agrobacterium mediated transformation system for chickpea wilt pathogen Fusarium oxysporum f. sp. ciceri using DsRed-Express to follow root colonisation. Microbiol. Res. 2012, 167, 332-338. [CrossRef]

135. Upasani, M.L.; Gurjar, G.S.; Kadoo, N.Y.; Gupta, V.S. Dynamics of colonization and expression of pathogenicity related genes in Fusarium oxysporum f. sp. ciceri during chickpea vascular wilt disease progression. PLoS ONE 2016, 11, e0156490. [CrossRef]

136. Niño-Sánchez, J.; Tello, V.; Casado-del Castillo, V.; Thon, M.R.; Benito, E.P.; Díaz-Mínguez, J.M. Gene expression patterns and dynamics of the colonization of common bean (Phaseolus vulgaris L.) by highly virulent and weakly virulent strains of Fusarium oxysporum. Front. Microbiol. 2015, 6, 234. [CrossRef]

137. Whalley, W.M.; Taylor, G.S. Influence of pea-root exudates on germination of conidia and chlamydospores of physiologic races of Fusarium oxysporum f. pisi. Ann. Appl. Biol. 1973, 73, 269-276. 
138. Stevenson, P.C.; Turner, H.C.; Haware, M.P. Phytoalexin accumulation in the roots of chickpea (Cicer arietinum L.) seedlings associated with resistance to fusarium wilt (Fusarium oxysporum f. sp. ciceri). Physiol. Mol. Plant Pathol. 1997, 50, 167-178. [CrossRef]

139. Kumar, Y.; Zhang, L.; Panigrahi, P.; Dholakia, B.B.; Dewangan, V.; Chavan, S.G.; Kunjir, S.M.; Wu, X.; Li, N.; Rajmohanan, P.R.; et al. Fusarium oxysporum mediates systems metabolic reprogramming of chickpea roots as revealed by a combination of proteomics and metabolomics. Plant Biotechnol. J. 2016, 14, 1589-1603. [CrossRef]

140. Bani, M.; Cimmino, A.; Evidente, A.; Rubiales, D.; Rispail, N. Pisatin involvement in the variation of inhibition of Fusarium oxysporum $\mathrm{f}$. sp. pisi spore germination by root exudates of Pisum spp. germplasm. Plant Pathol. 2018, 67, 1046-1054. [CrossRef]

141. Nóbrega, F.M.; Santos, I.S.; Da Cunha, M.; Carvalho, A.O.; Gomes, V.M. Antimicrobial proteins from cowpea root exudates: Inhibitory activity against Fusarium oxysporum and purification of a chitinase-like protein. Plant Soil 2005, 272, 223-232. [CrossRef]

142. Stevenson, P.C.; Padgham, D.E.; Haware, M.P. Root exudates associated with the resistance of four chickpea cultivars (Cicer arietinum) to two races of Fusarium oxysporum f.sp. ciceri. Plant Pathol. 1995, 44, 686-694. [CrossRef]

143. Castillejo, M.Á.; Bani, M.; Rubiales, D. Understanding pea resistance mechanisms in response to Fusarium oxysporum through proteomic analysis. Phytochemistry 2015, 115, 44-58. [CrossRef]

144. Upasani, M.L.; Limaye, B.M.; Gurjar, G.S.; Kasibhatla, S.M.; Joshi, R.R.; Kadoo, N.Y.; Gupta, V.S. Chickpea-Fusarium oxysporum interaction transcriptome reveals differential modulation of plant defense strategies. Sci. Rep. 2017, 7, 7746. [CrossRef]

145. Bishop, C.D.; Cooper, R.M. Ultrastructure of vascular colonization by fungal wilt pathogens. II. Invasion of resistant cultivars. Physiol. Plant Pathol. 1984, 24, 277-289. [CrossRef]

146. Sharma, K.D.; Chen, W.; Muehlbauer, F.J. Genetics of chickpea resistance to five races of Fusarium wilt and a concise set of race differentials for Fusarium oxysporum f. sp. ciceris. Plant Dis. 2005, 89, 385-390. [CrossRef]

147. Sharma, K.D.; Winter, P.; Kahl, G.; Muehlbauer, F.J. Molecular mapping of Fusarium oxysporum f. sp. ciceris race 3 resistance gene in chickpea. Theor. Appl. Genet. 2004, 108, 1243-1248. [CrossRef]

148. Tullu, A.; Muehlbauer, F.J.; Simon, C.J.; Mayer, M.S.; Kumar, J.; Kaiser, W.J.; Kraft, J.M. Inheritance and linkage of a gene for resistance to race 4 of fusarium wilt and RAPD markers in chickpea. Euphytica 1998, 102, 227-232. [CrossRef]

149. Tekeoglu, M.; Tullu, A.; Kaiser, W.J.; Muehlbauer, F.J. Inheritance and linkage of two genes that confer resistance to Fusarium wilt in chickpea. Crop Sci. 2000, 40, 1247. [CrossRef]

150. Grajal-Martìn, M.J.; Muehlbauer, F.J. Genomic location of the Fw gene for resistance to Fusarium wilt race 1 in peas. J. Hered. 2002, 93, 291-293. [CrossRef]

151. McClendon, M.T.; Inglis, D.A.; McPhee, K.E.; Coyne, C.J. DNA markers linked to Fusarium wilt race 1 resistance in pea. J. Am. Soc. Hortic. Sci. 2002, 127, 602-607. [CrossRef]

152. Coyne, C.J.; Inglis, D.A.; Whitehead, S.J.; McClendon, M.T.; Muehlbauer, F.J. Chromosomal location of Fwf, the Fusarium wilt race 5 resistance gene in Pisum sativum. Pisum Genet. 2000, 32, 20-22.

153. Okubara, P.; Ingis, D.; Muehlbauer, F.; Coyne, C. A novel RAPD marker linked to the Fusarium wilt race 5 resistance gene (Fwf) in Pisum sativum. Pisum Genet. 2002, 34, 6-8.

154. Ribeiro, R.L.D.; Hagedorn, D.J. Inheritance and nature of resistance in beans to Fusarium oxysporum $\mathrm{f}$. sp. phaseoli. Phytopathology 1979, 69, 859. [CrossRef]

155. Eujayl, I.; Erskine, W.; Bayaa, B.; Baum, M.; Pehu, E. Fusarium vascular wilt in lentil: Inheritance and identification of DNA markers for resistance. Plant Breed. 1998, 117, 497-499. [CrossRef]

156. Hamwieh, A.; Udupa, S.M.; Choumane, W.; Sarker, A.; Dreyer, F.; Jung, C.; Baum, M. A genetic linkage map of Lens sp. based on microsatellite and AFLP markers and the localization of fusarium vascular wilt resistance. Theor. Appl. Genet. 2005, 110, 669-677. [CrossRef]

157. Rubio, J.; Hajj-Moussa, E.; Kharrat, M.; Moreno, M.T.; Millan, T.; Gil, J. Two genes and linked RAPD markers involved in resistance to Fusarium oxysporum f. sp. ciceris race 0 in chickpea. Plant Breed. 2003, 122, 188-191. [CrossRef]

158. Halila, I.; Cobos, M.J.; Rubio, J.; Millán, T.; Kharrat, M.; Marrakchi, M.; Gil, J. Tagging and mapping a second resistance gene for Fusarium wilt race 0 in chickpea. Eur. J. Plant Pathol. 2009, 124, 87-92. [CrossRef] 
159. Singh, H.; Kumar, J.; Smithson, J.B.; Haware, M.P. Complementation between genes for resistance to race 1 of Fusarium oxysporum f. sp. ciceri in chickpea. Plant Pathol. 1987, 36, 539-543. [CrossRef]

160. Singh, H.; Kumar, J.; Haware, M.P.; Smithson, J.B. Genetics of resistance to fusarium wilt in chickpeas. In Genetics and Plant Pathogenesis; Day, P.R., Jellis, G.J., Eds.; Blackwell Scientific Publications: Oxford, UK, 1987; pp. 339-342.

161. Upadhyaya, H.D.; Haware, M.P.; Kumar, J.; Smithson, J.B. Resistance to wilt in chickpea. I. Inheritance of late-wilting in response to race 1. Euphytica 1983, 32, 447-452. [CrossRef]

162. Upadhyaya, H.D.; Smithson, J.B.; Haware, M.P.; Kumar, J. Resistance to wilt in chickpea. II. Further evidence for two genes for resistance to race 1. Euphytica 1983, 32, 749-755. [CrossRef]

163. Tullu, A.; Kaiser, W.J.; Kraft, J.M.; Muehlbauer, F.J. A second gene for resistance to race 4 of Fusarium wilt in chickpea and linkage with a RAPD marker. Euphytica 1999, 109, 43-50. [CrossRef]

164. Hijano, E.H.; Barnes, D.K.; Frosheiser, F.I. Inheritance of resistance to Fusarium wilt in alfalfa1. Crop Sci. 1983, 23, 31. [CrossRef]

165. Kamboj, R.K.; Pandey, M.P.; Chaube, H.S. Inheritance of resistance to Fusarium wilt in Indian lentil germplasm (Lens culinaris Medik.). Euphytica 1990, 50, 113-117. [CrossRef]

166. Cross, H.; Brick, M.A.; Schwartz, H.F.; Panella, L.W.; Byrne, P.F. Inheritance of resistance to Fusarium wilt in two common bean races. Crop Sci. 2000, 40, 954. [CrossRef]

167. Salgado, M.O.; Schwartz, H.F.; Brick, M.A. Inheritance of resistance to a Colorado race of Fusarium oxysporum f. sp. phaseoli in common beans. Plant Dis. 1995, 79, 279. [CrossRef]

168. Kwon, S.J.; Smýkal, P.; Hu, J.; Wang, M.; Kim, S.-J.; McGee, R.J.; McPhee, K.; Coyne, C.J. User-friendly markers linked to Fusarium wilt race 1 resistance $F w$ gene for marker-assisted selection in pea. Plant Breed. 2013, 132, 642-648. [CrossRef]

169. Cobos, M.J.; Fernández, M.J.; Rubio, J.; Kharrat, M.; Moreno, M.T.; Gil, J.; Millán, T. A linkage map of chickpea (Cicer arietinum $\mathrm{L}$.) based on populations from Kabuli $\times$ Desi crosses: Location of genes for resistance to fusarium wilt race 0. Theor. Appl. Genet. 2005, 110, 1347-1353. [CrossRef]

170. Jendoubi, W.; Bouhadida, M.; Millan, T.; Kharrat, M.; Gil, J.; Rubio, J.; Madrid, E. Identification of the target region including the Foc01/foc01 gene and development of near isogenic lines for resistance to Fusarium wilt race 0 in chickpea. Euphytica 2016, 210, 119-133. [CrossRef]

171. Gowda, S.J.M.; Radhika, P.; Kadoo, N.Y.; Mhase, L.B.; Gupta, V.S. Molecular mapping of wilt resistance genes in chickpea. Mol. Breed. 2009, 24, 177-183. [CrossRef]

172. Sharma, D.K.; Muehlbauer, F.J. Fusarium wilt of chickpea: Physiological specialization, genetics of resistance and resistance gene tagging. Euphytica 2007, 157, 1-14. [CrossRef]

173. Varshney, R.K.; Mohan, S.M.; Gaur, P.M.; Chamarthi, S.K.; Singh, V.K.; Srinivasan, S.; Swapna, N.; Sharma, M.; Pande, S.; Singh, S.; et al. Marker-assisted backcrossing to introgress resistance to Fusarium wilt race 1 and Ascochyta blight in C 214, an elite cultivar of chickpea. Plant Genome 2014, 7, 1-11. [CrossRef]

174. Pratap, A.; Chaturvedi, S.K.; Tomar, R.; Rajan, N.; Malviya, N.; Thudi, M.; Saabale, P.R.; Prajapati, U.; Varshney, R.K.; Singh, N.P. Marker-assisted introgression of resistance to fusarium wilt race 2 in Pusa 256, an elite cultivar of desi chickpea. Mol. Genet. Genom. 2017, 292, 1237-1245. [CrossRef]

175. Winter, P.; Benko-Iseppon, A.M.; Hüttel, B.; Ratnaparkhe, M.; Tullu, A.; Sonnante, G.; Pfaff, T.; Tekeoglu, M.; Santra, D.; Sant, V.J.; et al. A linkage map of the chickpea (Cicer arietinum L.) genome based on recombinant inbred lines from a C. arietinum $\times$ C. reticulatum cross: Localization of resistance genes for fusarium wilt races 4 and 5. Theor. Appl. Genet. 2000, 101, 1155-1163. [CrossRef]

176. Benko-Iseppon, A.M.; Winter, P.; Huettel, B.; Staginnus, C.; Muehlbauer, F.J.; Kahl, G. Molecular markers closely linked to fusarium resistance genes in chickpea show significant alignments to pathogenesis-related genes located on Arabidopsis chromosomes 1 and 5. Theor. Appl. Genet. 2003, 107, 379-386. [CrossRef]

177. Caballo, C.; Madrid, E.; Gil, J.; Chen, W.; Rubio, J.; Millan, T. Saturation of genomic region implicated in resistance to Fusarium oxysporum f. sp. ciceris race 5 in chickpea. Mol. Breed. 2019, 39, 1-11. [CrossRef]

178. Kreplak, J.; Madoui, M.A.; Cápal, P.; Novák, P.; Labadie, K.; Aubert, G.; Bayer, P.E.; Gali, K.K.; Syme, R.A.; Main, D.; et al. A reference genome for pea provides insight into legume genome evolution. Nat. Genet. 2019, 51, 1411-1422. [CrossRef]

179. Gupta, S.; Chakraborti, D.; Rangi, R.K.; Basu, D.; Das, S. A molecular insight into the early events of chickpea (Cicer arietinum) and Fusarium oxysporum f. sp. ciceri (race 1) interaction through cDNA-AFLP analysis. Phytopathology 2009, 99, 1245-1257. [CrossRef] 
180. Gupta, S.; Bhar, A.; Chatterjee, M.; Ghosh, A.; Das, S.; Gupta, V. Transcriptomic dissection reveals wide spread differential expression in chickpea during early time points of Fusarium oxysporum f. sp. ciceri. PLoS ONE 2017, 12, e0178164. [CrossRef]

181. Lanubile, A.; Muppirala, U.K.; Severin, A.J.; Marocco, A.; Munkvold, G.P. Transcriptome profiling of soybean (Glycine max) roots challenged with pathogenic and non-pathogenic isolates of Fusarium oxysporum. BMC Genom. 2015, 16, 1089. [CrossRef]

182. Gurjar, G.S.; Giri, A.P.; Gupta, V.S. Gene expression profiling during wilting in chickpea caused by Fusarium oxysporum f. sp. ciceri. Am. J. Plant Sci. 2012, 3, 190-201. [CrossRef]

183. Saabale, P.R.; Dubey, S.C.; Priyanka, K.; Sharma, T.R. Analysis of differential transcript expression in chickpea during compatible and incompatible interactions with Fusarium oxysporum f. sp. ciceris Race 4. 3 Biotech 2018, 8. [CrossRef]

184. Chen, L.; Wu, Q.; He, W.; He, T.; Wu, Q.; Miao, Y. Combined de novo transcriptome and metabolome analysis of common bean response to Fusarium oxysporum f. sp. phaseoli infection. Int. J. Mol. Sci. 2019, 20, 6278. [CrossRef]

185. Chang, C.; Tian, L.; Ma, L.; Li, W.; Nasir, F.; Li, X.; Tran, L.P.; Tian, C. Differential responses of molecular mechanisms and physiochemical characters in wild and cultivated soybeans against invasion by the pathogenic Fusarium oxysporum Schltdl. Physiol. Plant. 2019, 166, 1008-1025. [CrossRef]

186. Caballo, C.; Castro, P.; Gil, J.; Millan, T.; Rubio, J.; Die, J.V. Candidate genes expression profiling during wilting in chickpea caused by Fusarium oxysporum f. sp. ciceris race 5. PLoS ONE 2019, 14. [CrossRef]

187. Taylor, A.; Vágány, V.; Jackson, A.C.; Harrison, R.J.; Rainoni, A.; Clarkson, J.P. Identification of pathogenicity-related genes in Fusarium oxysporum f. sp. cepae. Mol. Plant Pathol. 2016, 17, 1032-1047. [CrossRef]

188. Ramos, B.; Alves-Santos, F.M.; García-Sánchez, M.A.; Martín-Rodrigues, N.; Eslava, A.P.; Díaz-Mínguez, J.M. The gene coding for a new transcription factor (ftf1) of Fusarium oxysporum is only expressed during infection of common bean. Fungal Genet. Biol. 2007, 44, 864-876. [CrossRef]

189. Niño-Sánchez, J.; Casado-Del Castillo, V.; Tello, V.; De Vega-Bartol, J.J.; Ramos, B.; Sukno, S.A.; Díaz Mínguez, J.M. The FTF gene family regulates virulence and expression of SIX effectors in Fusarium oxysporum. Mol. Plant Pathol. 2016, 17, 1124-1139. [CrossRef]

190. Thatcher, L.F.; Williams, A.H.; Garg, G.; Buck, S.A.G.; Singh, K.B. Transcriptome analysis of the fungal pathogen Fusarium oxysporum f. sp. medicaginis during colonisation of resistant and susceptible Medicago truncatula hosts identifies differential pathogenicity profiles and novel candidate effector. BMC Genom. 2016, 17. [CrossRef]

191. Thatcher, L.F.; Kidd, B.N.; Singh, K.B. Tools and strategies for genetic and molecular dissection of Medicago truncatula resistance against Fusarium wilt disease. In The Model Legume Medicago Truncatula; Bruijn, F.J., Ed.; Wiley-Blackwell: Hoboken, NJ, USA, 2020; pp. 331-339.

192. Gaur, P.M.; Gowda, C.L.L.; Knights, E.J.; Warkentin, T.; Acikoz, N.; Yadav, S.S.; Kumar, J. Breeding achievements. In Chickpea Breeding and Management; Yadav, S.S., Reden, R.J., Chen, W., Sharma, B., Eds.; Centre for Agriculture and Bioscience International (CABI): Wallingford, UK, 2007.

193. Salimath, P.M.; Toker, C.; Sandhu, J.S.; Kumar, J.; Suma, B.; Yadav, S.S.; Bahl, P.N. Conventional breeding methods. In Chickpea Breeding and Management; Yadav, S.S., Reden, R.J., Chen, W., Sharma, B., Eds.; Centre for Agriculture and Bioscience International (CABI): Wallingford, UK, 2007.

194. Gaur, P.M.; Jukanti, A.K.; Varshney, R.K. Impact of genomic technologies on chickpea breeding strategies. Agronomy 2012, 2, 199-221. [CrossRef]

195. Millán, T.; Madrid, E.; Cubero, J.I.; Amri, M.; Castro, P.; Rubio, J. Chickpea. In Grain Legumes; De Ron, A.M., Ed.; Springer: New York, NY, USA, 2015; pp. 85-109.

196. Castro, P.; Pistón, F.; Madrid, E.; Millán, T.; Gil, J.; Rubio, J. Development of chickpea near-isogenic lines for fusarium wilt. Theor. Appl. Genet. 2010, 121, 1519-1526. [CrossRef]

197. Jiang, G.-L. Molecular markers and marker-assisted breeding in plants. In Plant Breeding from Laboratories to Fields; InTech: London, UK, 2013.

198. Jones, J.D.G.; Dangl, J.L. The plant immune system. Nature 2006, 444, 323-329. [CrossRef]

199. Vleeshouwers, V.G.A.A.; Oliver, R.P. Effectors as tools in disease resistance breeding against biotrophic, hemibiotrophic, and necrotrophic plant pathogens. Mol. Plant Microbe Interact. 2014, 27, 196-206. 
200. Houterman, P.M.; Ma, L.; van Ooijen, G.; de Vroomen, M.J.; Cornelissen, B.J.C.; Takken, F.L.W.; Rep, M. The effector protein Avr2 of the xylem-colonizing fungus Fusarium oxysporum activates the tomato resistance protein I-2 intracellularly. Plant J. 2009, 58, 970-978. [CrossRef]

201. Kankanala, P.; Nandety, R.S.; Mysore, K.S. Genomics of plant disease resistance in legumes. Front. Plant Sci. 2019, 10. [CrossRef]

202. Curtin, S.J. Editing the Medicago truncatula genome: Targeted mutagenesis using the CRISPR-Cas9 reagent. In Functional Genomics in Medicago Truncatula. Methods in Molecular Biology; Cañas, L., Beltrán, J., Eds.; Humana Press Inc.: Totowa, NJ, USA, 2018; Volume 1822, pp. 161-174.

203. Curtin, S.J.; Xiong, Y.; Michno, J.M.; Campbell, B.W.; Stec, A.O.; Čermák, T.; Starker, C.; Voytas, D.F.; Eamens, A.L.; Stupar, R.M. CRISPR/Cas9 and TALENs generate heritable mutations for genes involved in small RNA processing of Glycine max and Medicago truncatula. Plant Biotechnol. J. 2018, 16, 1125-1137. [CrossRef]

204. Ji, J.; Zhang, C.; Sun, Z.; Wang, L.; Duanmu, D.; Fan, Q. Genome editing in cowpea Vigna unguiculata using CRISPR-Cas9. Int. J. Mol. Sci. 2019, 20, 2471. [CrossRef]

205. Almeida, N.F.; Leitão, S.T.; Krezdorn, N.; Rotter, B.; Winter, P.; Rubiales, D.; Vaz Patto, M.C. Allelic diversity in the transcriptomes of contrasting rust-infected genotypes of Lathyrus sativus, a lasting resource for smart breeding. BMC Plant Biol. 2014, 14, 376. [CrossRef]

206. Vaz Patto, M.C.; Fernandez-Aparicio, M.; Moral, A.; Rubiales, D. Characterization of resistance to powdery mildew (Erysiphe pisi) in a germplasm collection of Lathyrus sativus. Plant Breed. 2006, 125, 308-310. [CrossRef]

207. Lambein, F.; Travella, S.; Kuo, Y.-H.; Van Montagu, M.; Heijde, M. Grass pea (Lathyrus sativus L.): Orphan crop, nutraceutical or just plain food? Planta 2019, 250, 821-838. [CrossRef]

(C) 2020 by the authors. Licensee MDPI, Basel, Switzerland. This article is an open access article distributed under the terms and conditions of the Creative Commons Attribution (CC BY) license (http://creativecommons.org/licenses/by/4.0/). 